NBER WORKING PAPER SERIES

\title{
GLOBALIZATION AND THE INCREASING CORRELATION BETWEEN CAPITAL INFLOWS AND OUTFLOWS
}

\author{
J. Scott Davis \\ Eric van Wincoop \\ Working Paper 23671 \\ http://www.nber.org/papers/w23671 \\ NATIONAL BUREAU OF ECONOMIC RESEARCH \\ 1050 Massachusetts Avenue \\ Cambridge, MA 02138 \\ August 2017
}

We gratefully acknowledge financial support from the Bankard Fund for Political Economy and the Hong Kong Institute for Monetary Research. This paper represents the views of the authors, which are not necessarily the views of the Federal Reserve Bank of Dallas, the Federal Reserve System, or the National Bureau of Economic Research.

NBER working papers are circulated for discussion and comment purposes. They have not been peer-reviewed or been subject to the review by the NBER Board of Directors that accompanies official NBER publications.

(C) 2017 by J. Scott Davis and Eric van Wincoop. All rights reserved. Short sections of text, not to exceed two paragraphs, may be quoted without explicit permission provided that full credit, including $(\odot$ notice, is given to the source. 
Globalization and the Increasing Correlation between Capital Inflows and Outflows

J. Scott Davis and Eric van Wincoop

NBER Working Paper No. 23671

August 2017

JEL No. F3,F41

\title{
ABSTRACT
}

We document that the correlation between capital inflows and outflows has increased substantially over time in a sample of 128 advanced and developing countries. We provide evidence that this is a result of an increase in financial globalization (stock of external assets and liabilities). This dominates the effect of an increase in trade globalization (exports plus imports), which reduces the correlation between capital inflows and outflows. In the context of a twocountry model with 14 shocks we show that the theoretical impact of financial and trade globalization on the correlation between capital inflows and outflows is consistent with the data.

\author{
J. Scott Davis \\ Federal Reserve Bank of Dallas \\ Research Department \\ 2200 North Pearl Street \\ Dallas, TX 75201 \\ Scott.Davis@dal.frb.org \\ Eric van Wincoop \\ Department of Economics \\ University of Virginia \\ P.O. Box 400182 \\ Charlottesville, VA 22904-4182 \\ and NBER \\ vanwincoop@virginia.edu
}




\section{Introduction}

Gross international asset positions and capital flows have grown enormously in size over the past three decades, which has raised significant concerns about financial and macroeconomic stability in the face of surges and stops of capital flows. However, Forbes and Warnock (2012) point out that a sudden stop of capital inflows is increasingly accompanied by reduced outflows (retrenchment), dampening the impact on net flows. ${ }^{1}$ Similarly, large capital flight (outflows) is increasingly accompanied by a surge in capital inflows. Broner et al. (2013) document that capital inflows and outflows have become significantly more correlated in countries of all income levels from the 1980s to the 2000s and are highest in high-income countries. The objective of this paper is to shed light on what drives this phenomenon of increasingly correlated inflows and outflows.

There has been some discussion in the literature about why capital inflows and outflows would be positively correlated at all. Broner et al. (2013) argue that one would expect a negative correlation in a model with time-varying expected returns, as for example in RBC models with productivity shocks. A higher expected return in the United States should lead both US and foreign investors to shift their portfolio to the US, leading to larger US capital inflows and lower outflows. The same negative correlation between inflows and outflows can be expected when there are changes in the relative riskiness of US assets. Broner et al. (2013) argue that without financial or other frictions, we cannot explain the positive correlation between inflows and outflows.

Tille and van Wincoop (2010) provide a broader perspective on the relationship between capital inflows and outflows from a portfolio perspective. Capital flows have a portfolio growth component (associated with saving) and a portfolio reallocation component (e.g. due to changes in expected returns and risk). The portfolio growth component can generate a positive correlation between inflows and outflows when saving is positively correlated across countries. Portfolio reallocation generates a negative correlation between inflows and outflows when domestic and foreign agents face the same portfolio problem and therefore shift their portfolios in the same direction, as in the examples above. Broner et al. (2013) therefore emphasize that asymmetries across countries are needed to generate a positive correlation between inflows and outflows across countries.

Many examples of such asymmetries have been developed in the literature, leading to differences in expected returns and risk from the perspective of domestic and foreign investors and contributing to a positive correlation between capital inflows and outflows. Expected returns may be different across countries due to information asymmetries (Tille and van Wincoop (2014), Brennan and Cao (1997)) or to costs associated with investing abroad. Foreign assets may be perceived to be riskier due to exchange rate risk (Broner et al. (2013)) or expropriation risk (Gourio et al. (2016)). An increase in global risk or risk-aversion will then lead to a general retrenchment towards domestic assets, lowering both inflows and outflows. Such a global retrenchment is documented by MilesiFerretti and Tille (2011) for the 2008-2009 global financial crisis. ${ }^{2}$ Rey (2013) casts this more

\footnotetext{
${ }^{1}$ Throughout the paper capital inflows are net purchases of domestic assets by foreign residents and capital outflows are net purchases of foreign assets by domestic residents.

${ }^{2}$ Further evidence of retrenchment during the global financial crisis is in Giannetti and Laeven (2012) for the syndicated loan market.
} 
broadly as part of a global financial cycle. ${ }^{3}$ Tille and van Wincoop (2010) show that inflows and outflows become positively correlated due to various types of time-varying risk that impact foreign and domestic investors differently. This may be due to a different optimal hedge against inflation or future expected returns or non-asset income. ${ }^{4}$

In this paper the aim is not to explain a positive correlation between capital inflows and outflows, but rather the significant increase in this correlation over time and the much higher correlation in developed countries than in developing countries. For example, in Table 2 we report that among industrialized countries the correlation between capital inflows and outflows, normalized by external assets and liabilities, rose from 0.25 during 1970-1990 to 0.87 during 19902011. For emerging markets the increase was from 0.07 to 0.48. Similar numbers apply when we divide capital flows by GDP. The explanation for this phenomenon does not require larger asymmetries across countries, as the discussion above might suggest. It also does not require a larger size of the shocks that are responsible for a positive correlation between inflows and outflows, such as larger global risk shocks. The explanation is much simpler. We argue that it is a simple corollary of financial globalization.

To understand this better, it is useful to distinguish between net flows and gross flows. Net flows, $N F$, are equal to capital outflows minus inflows, which equals the current account. These are commonly referred to as "global imbalances." We define gross flows, GF, as the sum of capital outflows and inflows. It follows that

$$
\begin{aligned}
& \text { Outflows }=0.5 G F+0.5 N F \\
& \text { Inflows }=0.5 G F-0.5 N F
\end{aligned}
$$

It is immediate that gross flows generate a perfect positive correlation between inflows and outflows, while net flows generate a perfect negative correlation. A higher correlation between capital inflows and outflows is then simply the result of a higher volatility of gross flows relative to net flows. More precisely, assuming the same variance of inflows and outflows, so that net and gross flows are uncorrelated, we have

$$
\operatorname{corr}(\text { Outflows, Inflows })=\frac{[\operatorname{var}(G F) / \operatorname{var}(N F)]-1}{[\operatorname{var}(G F) / \operatorname{var}(N F)+1}
$$

We then need to explain the increase in the volatility of gross flows relative to the volatility of net flows.

We will argue that financial globalization (increased stock of external assets and liabilities)

\footnotetext{
${ }^{3}$ The empirical importance of such a global financial cycle for capital flows has been recently questioned by Cerutti, Claessens and Rose (2017). Gourio et.al. (2016) provide evidence that an increase in global risk reduces capital inflows and outflows of emerging markets.

${ }^{4}$ Another, very different, reason for different portfolio shifts of domestic and foreign agents that lead inflows and outflows to be positively correlated is associated with official capital flows. When capital inflows lead to an accumulation of reserves, they are combined with official outflows. We find this to be an important contributor to the correlation between total inflows and outflows of emerging markets. See also Bianchi, Hatchondo and Martinez (2016). Yet another explanation is bank liquidity management, suggested by Davis (2015), where banks reduce outflows to manage liquidity when faced with a drop in inflows.
} 
raises the volatility of gross flows relative to net flows, while trade globalization (higher imports and exports) does the opposite. Financial globalization has significantly outpaced trade globalization in recent decades, which accounts for the higher correlation between inflows and outflows.

We will confirm this explanation empirically by considering a sample of 128 countries with annual data from 1970 to 2011. We show both in cross section and panel data that financial globalization generates a higher correlation between capital inflows and outflows and a higher volatility of gross flows relative to net flows. The impact of trade globalization is more ambiguous, but the evidence points to a decrease in the correlation between capital inflows and outflows and a lower volatility of gross flows relative to net flows.

After documenting the empirical evidence, we develop a simple two period, two country model to shed light on the empirical findings. The model contains a wide variety of shocks: income shocks, expected asset payoff shocks, portfolio shocks, saving shocks, investment shocks and trade shocks. We then consider the impact of financial and trade globalization, while keeping the magnitude of all the shocks in the model unchanged. We do so by varying the parameters in the model that determine cross-border asset holdings and trade flows, holding all else fixed.

The results in the model are consistent with the data. Financial globalization raises the volatility of gross flows relative to net flows and therefore raises the correlation between capital inflows and outflows, while trade globalization does the opposite. Furthermore, we find that a proportional increase in both trade and financial integration still leads to an increase in the relative volatility of gross flows, and thus an increase in the correlation between inflows and outflows. So while the rapid increase in financial globalization relative to trade globalization that has taken place over the past three decades has certainly led to an increased correlation between inflows and outflows, an increase in the correlation would have occurred even if trade and financial globalization had progressed at the same pace.

The remainder of the paper is organized as follows. Section 2 presents the stylized facts in the data. Section 3 describes the model. Section 4 discusses the results implied by the model. Section 5 concludes.

\section{Empirical Evidence}

In this section we consider the empirical relationship between various capital flow moments and financial and trade globalization. Financial globalization is measured as the sum of external assets and liabilities divided by GDP, while trade globalization is measured as exports plus imports divided by GDP. There are 128 countries in the sample, split into groups of 25 advanced economies and 103 emerging and developing economies. The full list of countries is presented in Table 1.

Capital flow moments are calculated using annual data from 1970 to 2011. Gross capital inflow and outflow data, as well as export and import data, are from the IMF's International Financial Statistics database. Data for the stock of external assets and liabilities are from Lane and Milesi-Ferretti (2007), using their data update through 2011. 
Table 1: Countries in the Sample

\begin{tabular}{|c|c|c|c|}
\hline \multirow{2}{*}{$\frac{\text { Advanced }}{\text { Australia }}$} & \multicolumn{3}{|c|}{ Emerging Market and Developing } \\
\hline & Albania & Fiji & Morocco \\
\hline Austria & Algeria & Gabon & Myanmar \\
\hline Belgium & Angola & Georgia & Namibia \\
\hline Canada & Antigua and Barbuda & Ghana & Nicaragua \\
\hline Denmark & Argentina & Guatemala & Nigeria \\
\hline Finland & Armenia & Guyana & Oman \\
\hline France & Aruba & Honduras & Pakistan \\
\hline Germany & Azerbaijan & Hungary & Papua New Guinea \\
\hline Greece & Bangladesh & India & Paraguay \\
\hline Iceland & Belarus & Indonesia & Peru \\
\hline Ireland & Belize & Iraq & Philippines \\
\hline Israel & Bolivia & Jamaica & Poland \\
\hline Italy & Bosnia & Jordan & Romania \\
\hline Japan & Botswana & Kazakhstan & Russia \\
\hline Korea & Brazil & Kenya & Saint Lucia \\
\hline New Zeeland & Bulgaria & Kosovo & Saudi Arabia \\
\hline Norway & Cabo Verde & Kuwait & Slovakia \\
\hline Portugal & Cameroon & Kyrgyzstan & Slovenia \\
\hline Singapore & Cambodia & Laos & South Africa \\
\hline Spain & Chile & Latvia & Sri Lanka \\
\hline Sweden & China & Lebanon & Sudan \\
\hline Switzerland & Colombia & Lesotho & Suriname \\
\hline The Netherlands & Congo & Libya & Swaziland \\
\hline United Kingdom & Costa Rica & Lithuania & Syria \\
\hline \multirow[t]{10}{*}{ United States } & Cote d'Ivoire & Macedonia & Tajikistan \\
\hline & Croatia & Macao & Thailand \\
\hline & Cyprus & Malaysia & Trinidad and Tobago \\
\hline & Czech Republic & Maldives & Tunisia \\
\hline & Dominican Republic & Malta & Turkey \\
\hline & Ecuador & Mauritania & Ukraine \\
\hline & Egypt & Mauritius & Uruguay \\
\hline & El Salvador & Mexico & Venezuela \\
\hline & Equatorial Guinea & Moldova & Vietnam \\
\hline & Estonia & Mongolia & West Bank \\
\hline
\end{tabular}

\subsection{Descriptive statistics}

We will denote $O F=$ outflows and $I F=$ inflows. Net outflows are $N F=O F-I F$ and gross flows are $G F=O F+I F$. Table 2 provides four moments: the correlation between capital inflows and outflows, the standard deviations of net and gross capital flows and their ratio. In the top panel of the table, capital outflows and inflows in each country are normalized by the previous year's sum of external assets and liabilities. In the bottom panel the same capital flows are normalized by GDP in the previous year.

These statistics are presented for the pre-1990 sub-period (1970-1990) and the post-1990 subperiod (1990-2011) for both the advanced economies and the emerging markets. In addition, since capital outflows include central bank foreign exchange reserve accumulation, the statistics are presented both when reserve accumulation is included in capital outflows and when it is excluded.

Turning first to the advanced economy sample, under both normalizations there is a sizable increase in the correlation between capital outflows and inflows between the pre- and post-1990 periods. The increase is from 0.25 to 0.87 when scaled by external assets and liabilities, and from 0.41 to 0.91 when scaled by GDP. We know from equation (1), presented in the introduction, that 
there is a positive monotonic relationship between this correlation and the standard deviation of gross flows relative to the standard deviation of net flows. Table 2 indeed confirms that together with the sharp increase in the correlation between inflows and outflows there is a large increase in the standard deviation of gross flows relative to the standard deviation of net flows from the preto post-1990 periods.

The value of $S t d(G F) / S t d(N F)$, as well its change between sub-samples, is similar regardless of how we normalize capital flows. However, the normalization does affect the standard deviations of gross and net flows individually. When normalizing by the sum of external assets and liabilities, the standard deviation of gross flows barely changes between the two sub-samples and there is a sizable fall in the standard deviation of net flows. When normalizing by GDP, there is little change in the standard deviation of net flows, but there is a sizable increase in the standard deviation of gross flows across the two periods.

Emerging markets and developing countries also experienced an increase in the correlation between capital inflows and outflows across the sub-samples, though both the level of the correlation and its change are smaller than for advanced economies. The same is the case for the standard deviation of gross flows relative to the standard deviation of net flows. This is true whether or not reserve accumulation is included as part of capital outflows. Official reserve accumulation has virtually no effect on the statistics for advanced economies, but in emerging markets there is a sizable fall in the standard deviation of gross capital flows, and the correlation between inflows and outflows, when reserves are excluded. When capital inflows lead to an accumulation of reserves, capital outflows increase as well, as in Bianchi, Hatchondo and Martinez (2016).

A possible explanation for the increase in the correlation between capital inflows and outflows, as well as the higher correlation in advanced countries, is the higher degree of financial globalization. The bottom of Table 2 shows that between the earlier and later periods the stock of external assets and liabilities as a share of GDP more than tripled in the advanced economies, whereas it increased by about $60 \%$ in the emerging markets. Both country groups saw a similar, and much smaller, increase in the level of trade as a share of GDP. This change over time in financial and trade globalization is also illustrated in Figures 1 and 2. Figure 1 compares the two sub-periods for individual countries, while Figure 2 shows the time series for the average of both sets of countries. In almost all advanced countries there is a very large increase in external assets and liabilities as a fraction of GDP, while in most emerging markets the increase is far more modest. At the same time, the bottom charts of Figure 1 show that most countries in both groups either did not see an increase in trade or only a modest increase. Figure 2 shows that the average level of trade in advanced countries closely tracks that of emerging markets since the late 1970s. 
Table 2: Capital Flow Moments

\begin{tabular}{|c|c|c|c|c|}
\hline \multicolumn{5}{|c|}{ Normalize by External Assets and Liabilities } \\
\hline & Adv & nced & Emergi & Market \\
\hline & Pre-1990 & Post-1990 & Pre-1990 & Post-1990 \\
\hline \multicolumn{5}{|l|}{ Outflows incl. reserves } \\
\hline $\operatorname{Corr}(O F, I F)$ & 0.247 & 0.874 & 0.069 & 0.483 \\
\hline$S t d(N F)$ & 0.029 & 0.012 & 0.109 & 0.046 \\
\hline$S t d(G F)$ & 0.042 & 0.051 & 0.119 & 0.076 \\
\hline$\frac{S t d(G F)}{S t d(N F)}$ & 1.883 & 5.869 & 1.306 & 1.848 \\
\hline \multicolumn{5}{|l|}{ Outflows excl. reserves } \\
\hline $\operatorname{Corr}(O F, I F)$ & 0.219 & 0.876 & -0.019 & 0.294 \\
\hline $\operatorname{Std}(N F)$ & 0.028 & 0.012 & 0.086 & 0.043 \\
\hline$S t d(G F)$ & 0.039 & 0.051 & 0.080 & 0.056 \\
\hline$\frac{S t d(G F)}{S t d(N F)}$ & 1.974 & 5.708 & 0.963 & 1.324 \\
\hline \multicolumn{5}{|c|}{ Normalize by GDP } \\
\hline & \multicolumn{2}{|c|}{ Advanced } & \multicolumn{2}{|c|}{ Emerging Market } \\
\hline Outflows incl recorves & Pre-1990 & Post-1990 & Pre-1990 & Post-1990 \\
\hline $\operatorname{Corr}(O F, I F)$ & 0.410 & 0.909 & 0.132 & 0.652 \\
\hline$S t d(N F)$ & 0.019 & 0.024 & 0.051 & 0.044 \\
\hline $\operatorname{Std}(G F)$ & 0.043 & 0.152 & 0.063 & 0.087 \\
\hline$\frac{S t d(G F)}{S t d(N F)}$ & 2.263 & 6.328 & 1.437 & 2.235 \\
\hline \multicolumn{5}{|l|}{ Outflows excl. reserves } \\
\hline $\operatorname{Corr}(O F, I F)$ & 0.375 & 0.912 & -0.047 & 0.455 \\
\hline$S t d(N F)$ & 0.019 & 0.024 & 0.046 & 0.038 \\
\hline $\operatorname{Std}(G F)$ & 0.041 & 0.152 & 0.043 & 0.062 \\
\hline$\frac{S t d(G F)}{S t d(N F)}$ & 2.226 & 6.363 & 0.990 & 1.667 \\
\hline (Ext. Assets+Liab.)/GDP & 0.792 & 2.614 & 0.575 & 0.962 \\
\hline (Exports+Imports)/GDP & 0.350 & 0.450 & 0.366 & 0.490 \\
\hline
\end{tabular}


Figure 1: Financial and Trade Globalization, 1970-1990 versus 1991-2011.
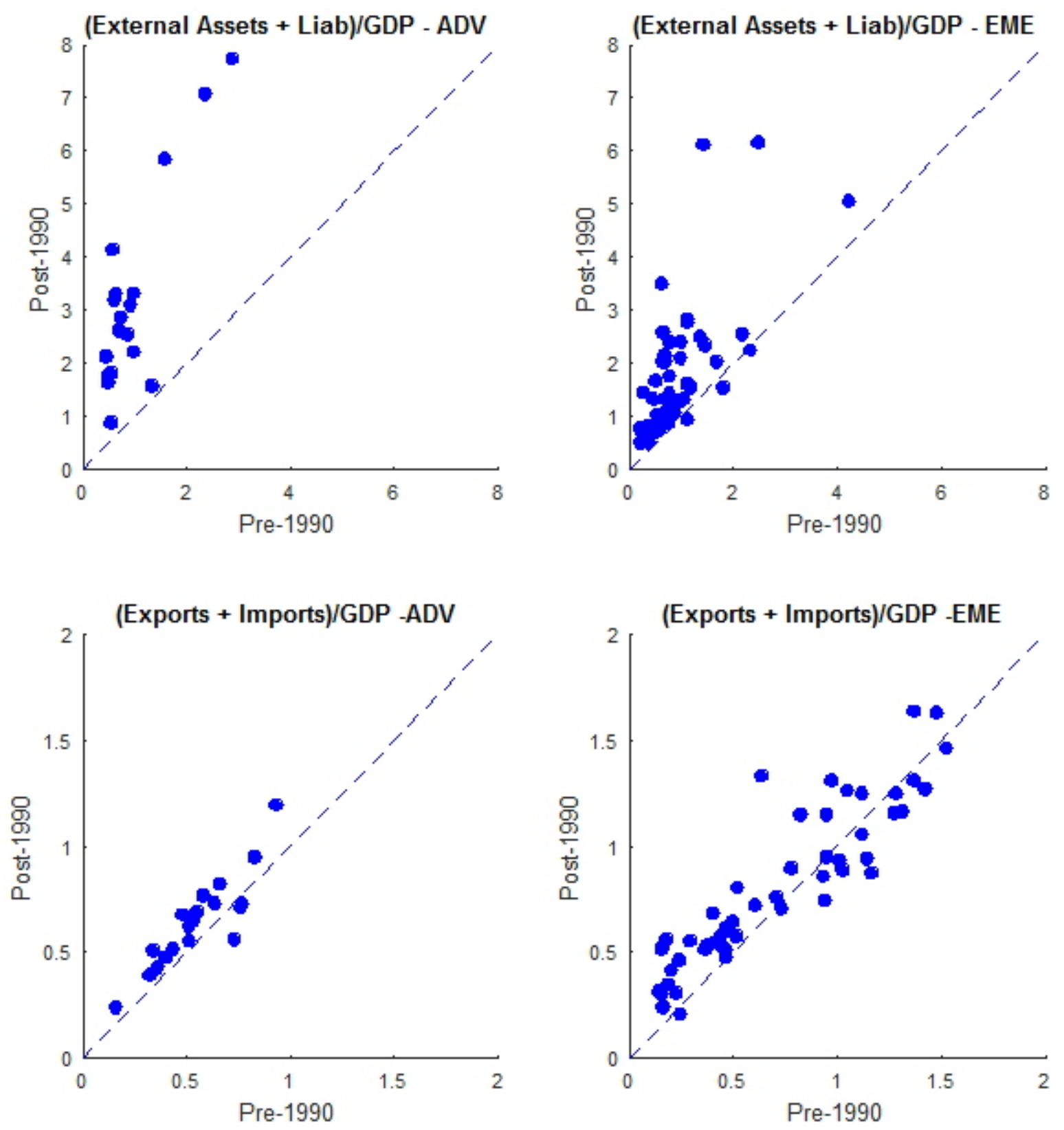
Figure 2: Financial and Trade Globalization, 1970-2011
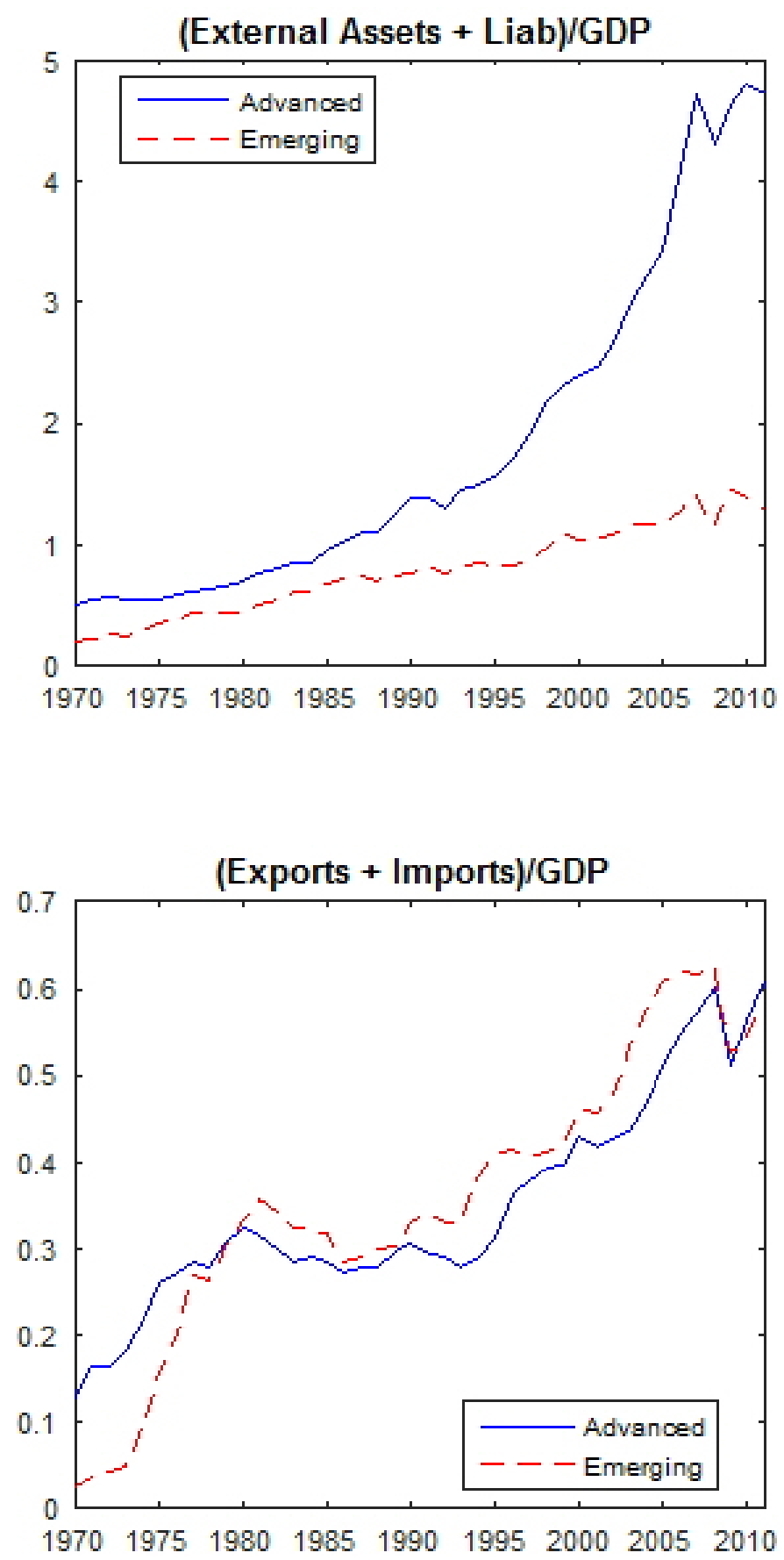
Table 3 presents results from multivariate regressions of the capital flow moments on financial and trade globalization. The top panel in the table presents the results from a cross-sectional regression, where the capital flow moments and averages of the independent variables for each country are calculated over the entire sample. The bottom panel presents the results from a panel data regression that uses the capital flow moments and averages of the independent variables for both the pre-1990 and post-1990 subsamples. The panel regression includes country-fixed effects.

The two regressions ask the same question in slightly different ways. The cross-sectional regression asks if across a sample of 128 countries, countries with a higher stock of external assets and liabilities tend to have more volatile gross capital flows and greater correlation between capital inflows and outflows. The panel data regression with country fixed effects instead asks if a change in financial or trade globalization leads to a change in the capital flow moments.

Table 3: Impact of Financial and Trade Globalization on Capital Flow Moments*

\begin{tabular}{|c|c|c|c|c|c|c|c|c|}
\hline \multicolumn{9}{|c|}{ Cross Section } \\
\hline & \multicolumn{4}{|c|}{ Capital Flows Normalized by External A\&L } & \multicolumn{4}{|c|}{ Capital Flows Normalized by GDP } \\
\hline & $\operatorname{Corr}(O F, I F)$ & $S t d(N F)$ & $S t d(G F)$ & $\frac{S t d(G F)}{S t d(N F)}$ & $\operatorname{Corr}(O F, I F)$ & $S t d(N F)$ & $\operatorname{Std}(G F)$ & $\frac{S t d(G F)}{\operatorname{Std}(N F)}$ \\
\hline$\frac{\text { External A\&L }}{G D P}$ & $\begin{array}{c}0.074^{* * *} \\
(0.029)\end{array}$ & $\begin{array}{c}-0.009^{* *} \\
(0.004)\end{array}$ & $\begin{array}{l}-0.006 \\
(0.005)\end{array}$ & $\begin{array}{c}2.768^{* * *} \\
(0.364)\end{array}$ & $\begin{array}{c}0.121^{* * *} \\
(0.026)\end{array}$ & $\begin{array}{l}-0.004 \\
(0.006)\end{array}$ & $\begin{array}{c}0.240^{* * *} \\
(0.022)\end{array}$ & $\begin{array}{c}4.653^{* * *} \\
(0.362)\end{array}$ \\
\hline$\frac{\text { Exports }+ \text { Imports }}{G D P}$ & $\begin{array}{c}0.018 \\
(0.077)\end{array}$ & $\begin{array}{l}0.020^{*} \\
(0.012)\end{array}$ & $\begin{array}{c}0.049^{* * *} \\
(0.014)\end{array}$ & $\begin{array}{l}-1.436 \\
(0.977)\end{array}$ & $\begin{array}{c}-0.117^{*} \\
(0.070)\end{array}$ & $\begin{array}{c}0.059^{* * *} \\
(0.015)\end{array}$ & $\begin{array}{l}-0.007 \\
(0.060)\end{array}$ & $\begin{array}{c}-3.059^{* * *} \\
(0.972)\end{array}$ \\
\hline $\bar{R}^{2}$ & 0.045 & 0.020 & 0.159 & 0.302 & 0.110 & 0.208 & 0.541 & 0.553 \\
\hline \multicolumn{9}{|c|}{ Panel (with cross-section fixed effects) } \\
\hline & \multicolumn{4}{|c|}{ Capital Flows Normalized by External A\&L } & \multicolumn{4}{|c|}{ Capital Flows Normalized by GDP } \\
\hline & $\operatorname{Corr}(O F, I F)$ & $\operatorname{Std}(N F)$ & $\operatorname{Std}(G F)$ & $\frac{\operatorname{Std}(G F)}{\operatorname{Std}(N F)}$ & $\operatorname{Corr}(O F, I F)$ & $\operatorname{Std}(N F)$ & $\operatorname{Std}(G F)$ & $\frac{\operatorname{Std}(G F)}{\operatorname{Std}(N F)}$ \\
\hline$\frac{\text { External A\&L }}{G D P}$ & $\begin{array}{c}0.131^{* * *} \\
(0.046)\end{array}$ & $\begin{array}{c}-0.014^{* *} \\
(0.007)\end{array}$ & $\begin{array}{c}0.004 \\
(0.008)\end{array}$ & $\begin{array}{c}1.881^{* * *} \\
(0.230)\end{array}$ & $\begin{array}{c}0.127^{* * *} \\
(0.049)\end{array}$ & $\begin{array}{c}0.008^{* *} \\
(0.003)\end{array}$ & $\begin{array}{c}0.175^{* * *} \\
(0.033)\end{array}$ & $\begin{array}{c}2.852^{* * * *} \\
(0.577)\end{array}$ \\
\hline$\frac{\text { Exports }+ \text { Imports }}{G D P}$ & $\begin{array}{c}0.131 \\
(0.317)\end{array}$ & $\begin{array}{c}0.017 \\
(0.045)\end{array}$ & $\begin{array}{c}0.037 \\
(0.055)\end{array}$ & $\begin{array}{c}0.254 \\
(1.584)\end{array}$ & $\begin{array}{c}0.183 \\
(0.336)\end{array}$ & $\begin{array}{c}0.028 \\
(0.023)\end{array}$ & $\begin{array}{c}0.216 \\
(0.227)\end{array}$ & $\begin{array}{c}5.014 \\
(3.985)\end{array}$ \\
\hline $\bar{R}^{2}$ & 0.172 & 0.193 & 0.033 & 0.738 & 0.080 & 0.629 & 0.494 & 0.336 \\
\hline
\end{tabular}

$\overline{\bar{*} \text { The table reports coefficients from multivariate regressions of capital flow moments on the stock of external assets and }}$ liabilities, as a share of GDP, and the sum of exports and imports as a share of GDP. The results in the top panel are from a cross-sectional regression with the moments for each country calculated over the entire sample period and the independent variables averaged over the sample period. The results in the bottom panel are from a panel data regression with the moments for each country calculated in the pre-1990 and post-1990 periods and the independent variables averaged over the pre-1990 and post-1990 periods. Standard errors are in parenthesis. $* * * / * * / *$ denotes significance at the $1 / 5 / 10 \%$ level.

First consider the cross section results. In line with our earlier intuition, financial globalization has a positive and significant effect on both the correlation between outflows and inflows and the closely related ratio of the standard deviations of gross flows and net flows. While the positive impact of financial globalization on the ratio of the standard deviations of gross and net flows is independent of the normalization of capital flows, the impact on the standard deviations of gross and net flows individually depends significantly on normalization. When capital flows are normalized by the stock of external assets and liabilities, financial globalization has a negative effect on the standard deviation of net flows and no effect on the standard deviation of gross flows. When instead capital flows are normalized by GDP, financial globalization has no effect on the 
standard deviation of net flows and a positive effect on the standard deviation of gross flows.

The effect of trade globalization in the cross sectional regressions is a bit more difficult to discern. Under both normalizations it has a positive effect on the volatility of net capital flows and lowers the volatility of gross flows relative to the volatility of net flows, though the latter is only statistically significant when capital flows are normalized by GDP. Trade globalization lowers the correlation between inflows and outflows when capital flows are normalized by GDP, but the result is insignificant when normalized by external assets and liabilities. The effect on the volatility of gross flows also depends a lot on the normalization.

Kalemli-Ozcan et al. (2013) argue that a cross-sectional regression can lead to a type of omitted variable bias. If there is some unobserved third factor that leads to a positive correlation between trade or financial openness and the variance of capital flows in the cross section, omitted variable bias may occur. This may be a time-invariant gravity variable. Portes and Rey (2005) argue that the same gravity variables that affect bilateral trade flows also affect financial flows. Since this unobserved third factor is time invariant, we can control for it with a country-fixed effect in a panel data regression.

The panel regression results are presented in the bottom half of Table 3. The impact of financial globalization remains the same as in the cross section regression. Countries that experienced a relative large increase in financial globalization across the sub-periods saw a larger increase in the correlation between capital inflows and outflows. In contrast to the cross section regressions, trade does not have a significant effect on capital flow moments in the panel regressions. This may be because the change in trade was not very large across the two sub-periods for most countries, as shown in the charts at the bottom of Figure 1. The change in financial globalization was much larger and more varied across countries.

Table 4 is analogous to Table 3, but uses the logs of the independent variables. The dependent variable in each regression remains the same. Qualitatively the results are identical to the earlier results. Table 4 can also be used to consider a proportional change in trade and financial globalization. This implies an equal change in the logs of the financial and trade globalization variables. The coefficients of all regressions in Table 4 imply that proportional globalization raises the correlation between capital inflows and outflows and raises the ratio of standard deviations of gross flows and net flows. 
Table 4: Impact of Financial and Trade Globalization on Capital Flow Moments*

\begin{tabular}{|c|c|c|c|c|c|c|c|c|}
\hline \multicolumn{9}{|c|}{ Cross Section } \\
\hline \multirow{4}{*}{$\begin{array}{c}\ln \left(\frac{\text { External A\&L }}{G D P}\right) \\
\ln \left(\frac{\text { Exports }+ \text { Imports }}{G D P}\right)\end{array}$} & $\operatorname{Corr}(O F, I F)$ & $\operatorname{Std}(N F)$ & $S t d(G F)$ & $\frac{S t d(G F)}{S t d(N F)}$ & $\operatorname{Corr}(O F, I F)$ & $\operatorname{Std}(N F)$ & $S t d(G F)$ & $\frac{S t d(G F)}{\operatorname{Std}(N F)}$ \\
\hline & $(0.064)$ & $(0.010)$ & $(0.012)$ & $(0.906)$ & $(0.058)$ & $(0.013)$ & $(0.059)$ & $(0.992)$ \\
\hline & -0.036 & $0.034^{* * *}$ & $0.062^{* * *}$ & -0.659 & $-0.167 * *$ & $0.050 * * *$ & 0.023 & $-2.010^{*}$ \\
\hline & $(0.072)$ & $(0.011)$ & $(0.014)$ & $(1.015)$ & $(0.065)$ & $(0.014)$ & $(0.066)$ & $(1.111)$ \\
\hline $\bar{R}^{2}$ & \multicolumn{8}{|c|}{ Panel (with cross-section fixed effects) } \\
\hline \multirow{2}{*}{$\begin{array}{c}\ln \left(\frac{\text { External A\&L }}{G D P}\right) \\
\ln \left(\frac{\text { Exports }+ \text { Imports }}{G D P}\right)\end{array}$} & \multicolumn{4}{|c|}{ Capital Flows Normalized by External A\&L } & \multicolumn{4}{|c|}{ Capital Flows Normalized by GDP } \\
\hline & $\operatorname{Corr}(O F, I F)$ & $\operatorname{Std}(N F)$ & $\operatorname{Std}(G F)$ & $\frac{S t d(G F)}{S t d(N F)}$ & $\operatorname{Corr}(O F, I F)$ & $S t d(N F)$ & $\operatorname{Std}(G F)$ & $\frac{S t d(G F)}{S t d(N F)}$ \\
\hline $\bar{R}^{2}$ & 0.256 & 0.259 & -0.036 & 0.325 & 0.168 & 0.611 & 0.159 & 0.109 \\
\hline
\end{tabular}

*The table reports coefficients from multivariate regressions of capital flow moments on the log of financial and trade globalization variables. The results in the top panel are from a cross-sectional regression with the moments for each country calculated over the entire sample period and the independent variables averaged over the sample period. The results in the bottom panel are from a panel data regression with the moments for each country calculated in the pre-1990 and post-1990 periods and the independent variables averaged over the pre-1990 and post-1990 periods. Standard errors are in parenthesis. $* * * / * * / *$ denotes significance at the $1 / 5 / 10 \%$ level.

We can summarize the results from this section in the form of a couple of stylized facts.

Stylized Fact 1 Financial globalization raises the correlation between capital inflows and outflows and raises the standard deviation of gross flows relative to the standard deviation of net flows.

Stylized Fact 2 When capital flows are normalized by external assets and liabilities, financial globalization lowers the volatility of net flows while it does not affect the volatility of gross flows. When capital flows are normalized by GDP, financial globalization has an effect on net flows that is not statistically significant or small, while it raises the volatility of gross flows.

Stylized Fact 3 The effect of trade globalization is somewhat ambiguous. Results that are statistically significant show that trade globalization lowers the correlation between capital inflows and outflows and the ratio of the volatilities of gross flows and net flows.

Stylized Fact 4 Proportional financial and trade globalization raises the correlation between capital inflows and outflows and the ratio of the volatilities of gross flows and net flows.

These results are also consistent with the findings from Table 2. They explain the higher correlation between capital inflows and outflows of advanced countries, especially in the second half of the sample. Stylized Fact 2 also explains the dependence on normalization of the changes in gross and net capital flow volatilities reported in Table 2. 


\section{The Model}

The model aims to shed light on the impact of financial and trade globalization on the correlation between capital inflows and outflows. The model consists of two countries (Home and Foreign), two periods, and two types of agents. The agents are native and global investors. Native investors in both countries only hold domestic assets, while global investors hold globally diversified portfolios. The extent of financial globalization is measured by the relative fraction of the global agents, which determines the size of external assets and liabilities in the absence of any shocks. The extent of trade globalization is driven by a home preference parameter in the consumption index of Home and Foreign goods. The objective will be to investigate how increases in financial and trade globalization affect the volatility of gross and net capital flows in response to various shocks, and therefore the correlation between capital inflows and outflows. There will be a total of 14 shocks (7 types of shocks in both Home and Foreign).

\subsection{Production and Investment}

There is a Home good and a Foreign good. Output in period $i=1,2$ is equal to productivity times the capital stock:

$$
\begin{aligned}
& Y_{H i}=A_{H i} K_{H i} \\
& Y_{F i}=A_{F i} K_{F i}
\end{aligned}
$$

In period 1 we assume that the capital stock is $K$ in both countries: $K_{H 1}=K_{F 1}=K$. Capital accumulates due to new investment:

$$
\begin{aligned}
& K_{H 2}=K+I_{H} \\
& K_{F 2}=K+I_{F}
\end{aligned}
$$

There is no depreciation. Productivity is equal to

$$
\begin{aligned}
& A_{H i}=A e^{\varepsilon_{H i}} \\
& A_{F i}=A e^{\varepsilon_{F i}}
\end{aligned}
$$

where $\varepsilon_{H i}$ and $\varepsilon_{F i}$ are Home and Foreign productivity shocks with mean 0 . We will also refer to $\varepsilon_{H 1}$ and $\varepsilon_{F 1}$ as current income shocks. Changes in the expectations $E\left(\varepsilon_{H 2}\right)$ and $E\left(\varepsilon_{F 2}\right)$ will be referred to as expected dividend shocks as they will affect expected asset payoffs. They are a type of news shock.

Capital goods are supplied by competitive installment firms. In the Home country they produce $I_{H}$ new capital goods in period 1 and sell them to firms at the price $Q_{H}$. Producing $I_{H}$ capital goods requires

$$
e^{-\varepsilon_{H}^{I}} I_{H}+\frac{\xi}{2} \frac{\left(I_{H}\right)^{2}}{K}
$$


of Home consumption goods. The price of Home consumption goods in period 1 is $P_{H 1}$. More generally we will denote Home and Foreign consumptions goods prices in period $i$ respectively $P_{H i}$ and $P_{F i}$. The installment firms maximize

$$
\Pi_{H}=Q_{H} I_{H}-P_{H 1}\left[e^{-\varepsilon_{H}^{I}} I_{H}+\frac{\xi}{2} \frac{\left(I_{H}\right)^{2}}{K}\right]
$$

This gives

$$
I_{H}=\frac{1}{\xi}\left(\frac{Q_{H}}{P_{H 1}}-e^{-\varepsilon_{H}^{I}}\right) K
$$

This is the Tobin Q model of investment. For the Foreign country we have analogously

$$
I_{F}=\frac{1}{\xi}\left(\frac{Q_{F}}{P_{F 1}}-e^{-\varepsilon_{F}^{I}}\right) K
$$

The shocks $\varepsilon_{H}^{I}$ and $\varepsilon_{F}^{I}$ will be referred to as investment shocks. If positive, they raise investment for given relative prices of capital and consumption goods.

\subsection{Saving and Portfolio Allocation}

Home agents maximize

$$
\ln C_{1}^{H}+\beta_{H} E \ln C_{2}^{H}
$$

where

$$
C_{i}^{H}=\left(\psi_{H i}^{\frac{1}{\omega}}\left(C_{H i}^{H}\right)^{\frac{\omega-1}{\omega}}+\left(1-\psi_{H i}\right)^{\frac{1}{\omega}}\left(C_{F i}^{H}\right)^{\frac{\omega-1}{\omega}}\right)^{\frac{\omega}{\omega-1}}
$$

Here $C_{i}^{H}$ is the consumption index of Home agents in period $i, C_{H i}^{H}$ is consumption of Home goods by Home agents and $C_{F i}^{H}$ is consumption of Foreign goods by Home agents. $\omega$ is the elasticity of substitution between Home and Foreign goods.

We assume

$$
\begin{aligned}
\frac{\beta_{H}}{1+\beta_{H}} & =\frac{\beta}{1+\beta} e^{\varepsilon_{H}^{\beta}} \\
1-\psi_{H i} & =(1-\psi) e^{\varepsilon_{H i}^{\psi}}
\end{aligned}
$$

$\varepsilon_{H}^{\beta}$ is a Home time discount rate shock, which we will also refer to as a saving shock. A positive value implies an increase in Home saving. $\varepsilon_{H i}^{\psi}, i=1,2$, are preference shocks, which we will also refer to as trade shocks. A positive value implies a shift towards Foreign goods and therefore an increase in trade. The equilibrium in period 1 will be affected by both period 1 trade shocks $\varepsilon_{H 1}^{\psi}$ and expectations of period 2 trade shocks, $E\left(\varepsilon_{H 2}^{\psi}\right)$. The parameter $\psi \in[0.5,1]$ captures a bias towards domestic goods. In the absence of shocks a fraction $\psi$ will be spent on domestic goods. As we lower $\psi$ from 1 to 0.5 , trade increases from zero (autarky) to its maximum level with perfect goods market integration. 
Foreign agents similarly maximize $\ln C_{1}^{F}+\beta_{F} E \ln C_{2}^{F}$, with

$$
C_{i}^{F}=\left(\left(1-\psi_{F i}\right)^{\frac{1}{\omega}}\left(C_{H i}^{F}\right)^{\frac{\omega-1}{\omega}}+\psi_{F i}^{\frac{1}{\omega}}\left(C_{F i}^{F}\right)^{\frac{\omega-1}{\omega}}\right)^{\frac{\omega}{\omega-1}}
$$

where $C_{H i}^{F}$ and $C_{F i}^{F}$ are demand for respectively Home and Foreign goods by Foreign agents and

$$
\begin{aligned}
\frac{\beta_{F}}{1+\beta_{F}} & =\frac{\beta}{1+\beta} e^{\varepsilon_{F}^{\beta}} \\
1-\psi_{F i} & =(1-\psi) e^{\varepsilon_{F i}^{\psi}}
\end{aligned}
$$

$\varepsilon_{F}^{\beta}$ and $\varepsilon_{F i}^{\psi}, i=1,2$, are the Foreign saving and trade shocks.

There is a Home asset and a Foreign asset. These assets are claims on period 2 output per unit of capital. The return from period 1 to period 2 on Home and Foreign assets is

$$
\begin{aligned}
R_{H} & =\frac{P_{H 2} A_{H 2}}{Q_{H}} \\
R_{F} & =\frac{P_{F 2} A_{F 2}}{Q_{F}}
\end{aligned}
$$

Now consider the consumption and portfolio decisions. There are native investors and global investors in both countries. Native investors only hold claims on domestic assets, while global investors optimally diversify across Home and Foreign assets. In each country there are $m$ global investors and $1-m$ native investors. The parameter $m$ is critical as it will determine the size of external assets and liabilities and therefore financial globalization.

Parameterizing financial globalization this way has the appeal that an increase in $m$ implies not only larger external financial assets and liabilities, but also a larger portfolio response to an expected return differential between Home and Foreign assets. In models where home bias shows up additively in portfolios, for example as a result of a cost of investing abroad that lowers the return, the extent of return arbitrage is independent of the extent of financial integration. A different approach that delivers the same positive relationship between external claims and return arbitrage assumes that there is a friction $\tau$ that captures an information asymmetry, implying a perceived variance of returns that is a factor $1+\tau$ larger for foreign agents than domestic agents. When $\tau=2(1-m) / m$, this generates the same equilibrium as in our model. ${ }^{5}$

At the start of period 1 , the native investors hold a fraction $1-m$ of the domestic capital stock. Home and Foreign global investors hold the same portfolio at the start of period 1. Both hold a fraction $0.5 \mathrm{~m}$ of Home and Foreign capital. The wealth of Home and Foreign native investors in period 1 is then

$$
\begin{aligned}
& W_{H}^{n}=(1-m) P_{H 1} Y_{H 1}+(1-m) Q_{H} K+\Pi_{H} \\
& W_{F}^{n}=(1-m) P_{F 1} Y_{F 1}+(1-m) Q_{F} K+\Pi_{F}
\end{aligned}
$$

\footnotetext{
${ }^{5}$ Okawa and van Wincoop (2012) develop a gravity theory of bilateral asset holdings based on such an asymmetric information framework, with bilateral variation in the friction $\tau$.
} 
The wealth consists of the dividends from the asset claims at the start of period 1 plus the principal value of the claims plus the profits from the installment firms. The assumption that the profits from installment firms goes to the native investors is just a technicality as it drops out with linearization.

The wealth of the Home and Foreign global investors is

$$
W=W_{H}^{g}=W_{F}^{g}=0.5 m\left(P_{H 1} Y_{H 1}+P_{F 1} Y_{F 1}\right)+0.5 m\left(Q_{H}+Q_{F}\right) K
$$

The wealth is the same for Home and Foreign global investors and equal to the dividends and principal value from the claims of a fraction $0.5 \mathrm{~m}$ of both Home and Foreign assets.

Global investors make both saving and portfolio decisions, while native investors only make a saving decision. Native investors receive the domestic return in period $2, R_{H}$ for Home native investors and $R_{F}$ for Foreign native investors. Home global investors receive a portfolio return in period 2 of

$$
R^{p, H}=z_{H} R_{H}+\left(1-z_{H}\right) R_{F}
$$

where $z_{H}$ is the share invested in Home assets. The portfolio return of Foreign global investors, $R^{p, F}$, is the same, with the portfolio share in Home asset $z_{F}$.

As a result of log utility, optimal consumption decisions do not depend on expected portfolio returns. Both Home native and global investors consume a fraction $1 /\left(1+\beta_{H}\right)$ of their wealth and save a fraction $\beta_{H} /\left(1+\beta_{H}\right)$. Aggregate consumption by Home agents in both periods is then

$$
\begin{aligned}
P_{1}^{H} C_{1}^{H} & =\frac{1}{1+\beta_{H}}\left(W_{H}^{n}+W\right) \\
P_{2}^{H} C_{2}^{H} & =\frac{\beta_{H}}{1+\beta_{H}}\left(W_{H}^{n} R_{H}+W R^{p, H}\right)
\end{aligned}
$$

with consumption allocated across the two goods according to

$$
\begin{aligned}
& C_{H i}^{H}=\psi_{H i}\left(\frac{P_{H i}}{P_{i}^{H}}\right)^{-\omega} C_{i}^{H} \\
& C_{F i}^{H}=\left(1-\psi_{H i}\right)\left(\frac{P_{F i}}{P_{i}^{H}}\right)^{-\omega} C_{i}^{H}
\end{aligned}
$$

where $P_{i}^{H}$ is the consumption price index of Home agents, which is

$$
P_{i}^{H}=\left(\psi_{H i}\left(P_{H i}\right)^{1-\omega}+\left(1-\psi_{H i}\right)\left(P_{F i}\right)^{1-\omega}\right)^{\frac{1}{1-\omega}}
$$

Analogous equations apply to Foreign agents.

The first-order condition of portfolio choice of Home global investors is

$$
E \frac{1}{R^{p, H}}\left(R_{H}-R_{F}\right)=0
$$


In terms of logs this is

$$
E e^{r_{H}-r^{p, H}}=E e^{r_{F}-r^{p, H}}
$$

Using the log linear approximation $r^{p, H}=z_{H} r_{H}+\left(1-z_{H}\right) r_{F}$, defining the excess return er $=$ $r_{H}-r_{F}$, and assuming normality of log returns, we can solve for the optimal portfolio:

$$
z_{H}=0.5+\frac{E(e r)+\varepsilon_{H}^{e r}}{\operatorname{var}(e r)}
$$

Analogous for example to Devereux and Engel (2002) and Hau (1998), we assume that the expectation of the excess return is $E(e r)+\varepsilon_{H}^{e r}$, which is the sum of the rational expectation $E(e r)$ and an expectational error.

We will write $\varepsilon_{H}^{z}=\varepsilon_{H}^{e r} / \operatorname{var}(e r)$, so that

$$
z_{H}=0.5+\frac{E(e r)}{\operatorname{var}(e r)}+\varepsilon_{H}^{z}
$$

Here $\varepsilon_{H}^{z}$ is an exogenous portfolio shock. While the portfolio shocks are the result of expectational errors, we will think of them more broadly as any type of financial shocks generating portfolio shifts. Depending on the specification, this can take the form of liquidity trade, noise trade, timevarying risk (Tille and van Wincoop $(2010,2014)$ ), time-varying risk-bearing capacity (Gabaix and Maggiori (2015)), time-varying costs of investment abroad (Bacchetta and van Wincoop (2017)) or time-varying private investment opportunities (Wang (1994)). ${ }^{6}$ The specification for Foreign global investors is analogous:

$$
z_{F}=0.5+\frac{E(e r)}{\operatorname{var}(e r)}-\varepsilon_{F}^{z}
$$

An increase in both $\varepsilon_{H}^{z}$ and $\varepsilon_{F}^{z}$ then generates a global retrenchment towards domestic assets. This may be part of a global financial cycle as Rey (2013) has suggested. In the absence of any shocks to the model, $z_{H}=z_{F}=0.5$, so both Home and Foreign global investors hold perfectly diversified portfolios.

Capital outflows and inflows are equal to

$$
\begin{aligned}
& O F=\frac{\beta_{H}}{1+\beta_{H}}\left(1-z_{H}\right) W-0.5 m K Q_{F} \\
& I F=\frac{\beta_{F}}{1+\beta_{F}} z_{F} W-0.5 m K Q_{H}
\end{aligned}
$$

These external asset purchases are equal to the value of external positions in period 1 minus the value of the positions at the start of period 1, which they carry over from the previous period.

\footnotetext{
${ }^{6}$ Itskhoki and Mukhin (2017) argue that such financial shocks can explain most puzzles associate with nominal and real exchange rates.
} 


\subsection{Market Clearing Conditions}

The asset market clearing conditions are

$$
\begin{aligned}
& \frac{\beta_{H}}{1+\beta_{H}}\left(W_{H}^{n}+z_{H} W\right)+\frac{\beta_{F}}{1+\beta_{F}} W z_{F}=Q_{H}\left(K+I_{H}\right) \\
& \frac{\beta_{H}}{1+\beta_{H}}\left(1-z_{H}\right) W+\frac{\beta_{F}}{1+\beta_{F}}\left(W_{F}^{n}+\left(1-z_{F}\right) W\right)=Q_{F}\left(K+I_{F}\right)
\end{aligned}
$$

In the Home asset market clearing condition (37), the first term on the right hand side is the sum of Home asset demand by the Home native agents, $\left[\beta_{H} /\left(1+\beta_{H}\right)\right] W_{H}^{n}$, and Home asset demand by global agents in the Home country, $\left[\beta_{H} /\left(1+\beta_{H}\right)\right] W z_{H}$. The second term is Home asset demand by Foreign global agents. The right hand side is the value of Home capital after investment.

The period 1 goods market clearing conditions are

$$
\begin{aligned}
& C_{H 1}^{H}+C_{H 1}^{F}+e^{-\varepsilon_{H}^{I}} I_{H}+\frac{\xi}{2} \frac{\left(I_{H}\right)^{2}}{K}=Y_{H 1} \\
& C_{F 1}^{H}+C_{F 1}^{F}+e^{-\varepsilon_{F}^{I}} I_{F}+\frac{\xi}{2} \frac{\left(I_{F}\right)^{2}}{K}=Y_{F 1}
\end{aligned}
$$

The period 2 goods market clearing conditions are

$$
\begin{aligned}
& C_{H 2}^{H}+C_{H 2}^{F}=Y_{H 2} \\
& C_{F 2}^{H}+C_{F 2}^{F}=Y_{F 2}
\end{aligned}
$$

\subsection{Shocks}

There are a total of 14 shocks, which are listed in Table 5. Ten shocks are current (period 1) shocks, while four are news shocks in the form of changing expectations of period 2 innovations. The latter include expected period 2 dividend innovations and trade innovations. For convenience of the analysis, we will rewrite all shocks as average shocks and relative shocks. For example, we transform the saving shocks $\varepsilon_{H}^{\beta}$ and $\varepsilon_{F}^{\beta}$ into an average saving shock and a relative saving shock:

$$
\begin{aligned}
& \varepsilon^{\beta, A}=0.5\left(\varepsilon_{H}^{\beta}+\varepsilon_{F}^{\beta}\right) \\
& \varepsilon^{\beta, D}=\varepsilon_{H}^{\beta}-\varepsilon_{F}^{\beta}
\end{aligned}
$$

Throughout we will use the superscript $A$ to denote an average across countries and superscript $D$ to denote the difference (Home minus Foreign variable).

\subsection{Solution}

There are six market equilibrium equations. After substituting the expressions for consumption, investment, wealth and portfolio shares into the six market equilibrium conditions, they depend on six variables: Home and Foreign goods prices in both periods and the Home and Foreign asset 
Table 5: Model Shocks

\begin{tabular}{|l|l|}
\hline Saving Shocks & $\varepsilon_{H}^{\beta}, \varepsilon_{F}^{\beta}$ \\
Investment Shocks & $\varepsilon_{H}^{\beta}, \varepsilon_{F}^{\beta}$ \\
Current Income Shocks & $\varepsilon_{H 1}, \varepsilon_{F 1}$ \\
Expected Dividend Shocks & $E\left(\varepsilon_{H 2}\right), E\left(\varepsilon_{F 2}\right)$ \\
Current Trade Shocks & $\varepsilon_{H 1}^{\psi}, \varepsilon_{F 1}^{\psi}$ \\
Expected Trade Shocks & $E\left(\varepsilon_{H 2}^{\psi}\right), E\left(\varepsilon_{F 2}^{\psi}\right)$ \\
Portfolio Shocks & $\varepsilon_{H}^{z}, \varepsilon_{F}^{z}$ \\
\hline
\end{tabular}

prices in period 1. We log-linearize around the point where there are no shocks. We then take the averages and differences of the market clearing conditions across countries. We refer to the average of Home and Foreign market clearing conditions as the global market clearing condition. We refer to the difference between Home and Foreign market clearing conditions as the relative market clearing condition.

Denoting logs of variables with lower case letters, the averages and differences across countries of the endogenous variables are: $p_{1}^{A}, p_{2}^{A}, p_{1}^{D}, p_{2}^{D}, q^{D}$ and $q^{A}$. Here $p_{i}^{A}=0.5\left(p_{H i}+p_{F i}\right), p_{i}^{D}=p_{H i}-p_{F i}$, $q^{D}=q_{H}-q_{F}$ and $q^{A}=0.5\left(q_{H}+q_{F}\right)$. Because of Walras' Law, two of the market clearing conditions are redundant (one per period). We remove the first and second period global goods market clearing condition, which are the same as the global asset market clearing condition. Correspondingly, we can remove two variables. Since the model only determines relative prices, we normalize the average of the $\log$ goods prices in both periods to be to $0: p_{1}^{A}=p_{2}^{A}=0$.

This leaves us with four equations in four variables. The equations are (1) the global asset market clearing condition, (2) the relative asset market clearing condition, (3) the relative period 1 goods market clearing condition and (4) the relative period 2 goods market clearing condition. The second and third equations have an alternative, intuitive interpretation as well. The current account (CA), defined as the trade account plus net investment income, is identical to both saving minus investment $(\mathrm{S}-\mathrm{I})$ and net capital outflows $(\mathrm{NF})$. The second equation (relative asset market clearing condition) is the exact same equation as $S-I=N F$. The third equation (relative period 1 goods market clearing condition) is the same as $C A=S-I$. Here $C A, N F$ and $S-I$ are all for the Home country.

We leave all algebraic details to the Online Technical Appendix. The global asset market clearing condition can be used to solve for the average asset price:

$$
q^{A}=\frac{1}{1+\frac{1+\beta}{\xi}}\left(\varepsilon_{1}^{A}+(1+\beta) \varepsilon^{\beta, A}-\frac{1+\beta}{\xi} \varepsilon^{I, A}\right)
$$

Intuitively, a positive average current income shock (positive $\varepsilon_{1}^{A}$ ) and a positive average saving shock (positive $\varepsilon^{\beta, A}$ ) both raise global saving and therefore asset demand, which raises the average asset price. A positive average investment shock (positive $\varepsilon^{I, A}$ ) raises the global asset supply, which lowers the average asset price. 
The other three market clearing conditions are

$$
\begin{aligned}
& S-I=N F \\
& C A=S-I \\
& (2 \psi-1) \varepsilon^{\beta, D}-\lambda p_{2}^{D}+\left((2 \psi-1) \frac{1-m}{1+\beta}+\frac{1}{\xi}\right)\left(p_{1}^{D}-q^{D}\right)-\frac{1}{\xi} \varepsilon^{I, D}+ \\
& \quad(2 \psi-1) \frac{1-m}{1+\beta} \varepsilon_{1}^{D}-2(1-\psi) \varepsilon_{2}^{\psi, D}=(1-(2 \psi-1)(1-m)) \varepsilon_{2}^{D}
\end{aligned}
$$

where $\lambda=4 \psi(1-\psi) \omega+(2 \psi-1)(2 \psi+m-2)$ and $C A, S-I$ and $N F$, scaled by external assets $0.5 \mathrm{mK}$ in the absence of shocks, are

$$
\begin{aligned}
\frac{N F}{\text { External Assets }}= & \varepsilon^{\beta, D}-4 \frac{E\left(p_{2}^{D}\right)+E\left(\varepsilon_{2}^{D}\right)-q^{D}}{\operatorname{var}(e r)}-2 \varepsilon^{z, D}+q_{D} \\
\frac{S-I}{\text { External Assets }}= & \frac{1-m}{(1+\beta) m}\left(p_{1}^{D}+\varepsilon_{1}^{D}-q_{D}\right)+\frac{\varepsilon^{\beta, D}}{m}-\frac{1}{m \xi}\left(q^{D}-p_{1}^{D}+\varepsilon^{I, D}\right) \\
\frac{C A}{\text { External Assets }}= & \frac{4 A \psi(1-\psi)(1-\omega)}{m} p_{1}^{D}+\frac{2(1-\psi)}{m} \varepsilon^{\beta, D}-\frac{2(1-\psi) A}{m} \varepsilon_{1}^{\psi, D} \\
& -\frac{2(1-\psi)(1-m)}{m(1+\beta)}\left(A p_{1}^{D}+A \varepsilon_{1}^{D}+q^{D}\right)-A\left(p_{1}^{D}+\varepsilon_{1}^{D}\right)
\end{aligned}
$$

Combining (44), (45) and the period 1 expectation of (46), we can solve jointly for $p_{1}^{D}, q^{D}$ and $E\left(p_{2}^{D}\right)$.

\subsection{Gross and Net Capital Flows}

Using the solution for $q^{A}$, we have a closed form solution for gross flows $G F=O F+I F$ as a fraction of external assets:

$$
\frac{G F}{\text { External Assets }}=\frac{2}{1+\beta+\xi}\left((1+\beta) \varepsilon^{\beta, A}+\varepsilon_{1}^{A}+\varepsilon^{I, A}\right)-4 \varepsilon^{z, A}
$$

Four shocks drive gross flows. The first two shocks, $\varepsilon^{\beta, A}$ and $\varepsilon_{1}^{A}$, raise global saving, which raises gross capital flows through a portfolio growth effect. Without a change in portfolio allocation, higher saving leads to an increase in demand of both domestic and foreign assets. The third shock, the average investment shock $\varepsilon^{I, A}$, reduces the average asset price $q^{A}$, which lowers consumption and therefore also raises global saving. The last shock, $\varepsilon^{z, A}$, is a global portfolio shift towards domestic assets (retrenchment), which reduces gross capital flows. An example of this is a global increase in risk or risk-aversion that leads to a retrenchment towards domestic assets, as occurred during the Great Recession (Milesi-Ferretti and Tille (2011)). Using the now popular terminology introduced by Rey (2013), one can think of $\varepsilon^{z, A}$ as a shock to the global financial cycle.

Substituting the solution for $p_{1}^{D}, q^{D}$ and $E\left(p_{2}^{D}\right)$ in the expression (47) for $N F$ gives a solution for net capital flows. One can think of net capital flows from a portfolio perspective $(N F)$, a saving minus investment perspective $(S-I)$ or a trade perspective $(C A)$. Relative goods and 
asset prices will adjust to make sure these are always the same.

Net capital flows depend on 7 shocks. Three shocks originate from the saving/investment side. An increase in $\varepsilon^{\beta, D}$ raises relative Home saving. From a portfolio perspective this leads to net capital outflows by global investors through two channels. The first is portfolio growth, where a fraction of the higher saving by global investors is invested abroad. The second effect is more indirect and operates through portfolio reallocation. The higher relative saving of Home native agents raises relative demand for Home assets, which raises $q^{D}$. The higher relative price of Home assets lowers the expected excess return on Home assets, which leads to portfolio reallocation to Foreign assets by global investors.

A positive relative income shock $\varepsilon_{1}^{D}$ also raises relative Home saving, but only of the native agents. It therefore has no portfolio growth effect on capital flows. The higher relative Home saving does lead to a rise in $q^{D}$, which, analogous to the relative saving shock, leads to a reallocation to Foreign assets by global investors (net outflows).

A positive relative Home investment shock $\varepsilon^{I, D}$ raises the relative supply of Home assets, which lowers the relative price $q^{D}$. The lower relative Home asset price raises the expected excess return on Home assets, which leads to net capital inflows associated with portfolio reallocation by global investors.

Two shocks that affect net capital flows originate from the trade side. A positive $\varepsilon_{1}^{\psi, D}$ implies a preference shock towards Foreign goods, which leads to a Home trade deficit. From a portfolio perspective, the following happens. The preference shock to Foreign goods raises the relative price of Foreign goods, which raises relative Foreign income and saving of native agents. This raises the relative demand for Foreign assets, which lowers $q^{D}$. This raises the expected excess return on Home assets and generates capital inflows through portfolio reallocation by global investors.

A positive $E\left(\varepsilon_{2}^{\psi, D}\right)$ implies an expected preference shock towards Foreign goods in the next period, which raises the expected period 2 relative price of Foreign goods. This raises the expected relative return on Foreign assets, leading to net capital outflows.

Two shocks affecting net capital flows originate directly from the portfolio side. A positive $\varepsilon^{z, D}$ implies an exogenous portfolio shift towards Home assets, leading to net capital inflows. A rise in $E\left(\varepsilon_{2}^{D}\right)$ raises the expected relative Home dividends, which raises the expected excess return on Home assets and also generates net capital inflows.

Three shocks affect neither inflows nor outflows. These are $E\left(\varepsilon_{2}^{A}\right), \varepsilon_{1}^{\psi, A}$ and $E\left(\varepsilon_{2}^{\psi, A}\right) . E\left(\varepsilon_{2}^{A}\right)$ affects portfolio returns, but not excess returns. As a result of the assumed log utility, expected portfolio returns do not affect the saving decision and therefore do not impact capital flows. $\varepsilon_{1}^{\psi, A}$ is a global trade home bias shock. It affects the trade volume (exports plus imports), but not net trade flows or gross capital flows. The same is the case for $E\left(\varepsilon_{2}^{\psi, A}\right)$. 


\section{Model Implications for Capital Flow Moments}

We now discuss the implications of the model for the correlation between capital inflows and outflows. It is useful to repeat (1):

$$
\operatorname{corr}(I F, O F)=\frac{[\operatorname{var}(G F) / \operatorname{var}(N F)]-1}{[\operatorname{var}(G F) / \operatorname{var}(N F)+1}
$$

There is therefore a positive relationship between the correlation between inflows and outflows and the relative volatility of gross flows and net flows. We will consider the impact of financial and trade globalization on this relative volatility. Since in the absence of shocks external assets are $0.5 \mathrm{mK}$ and imports $=$ exports $=(1-\psi) A K$, we can measure financial and trade globalization respectively with the parameters $m$ and $1-\psi$.

The impact of financial globalization on the volatilities of gross and net flows depends on whether we scale capital flows by external assets $(0.5 \mathrm{~m} K)$, GDP $(A K)$ or we do not scale at all. However, the impact of both financial and trade globalization parameters on the relative volatility of gross flows and net flows does not depend on scaling. Most of the results will be based on scaling capital flows by external assets $0.5 \mathrm{mK}$ as we will see that this simplifies the analysis. But it is important to emphasize that the scaling does not matter for the correlation between inflows and outflows.

A priori it is not immediately clear that financial globalization would imply a higher correlation between inflows and outflows. One might expect that financial globalization increases both the volatility of gross flows and net flows. We find that financial globalization indeed increases the volatility of gross flows when divided by GDP, while numerical results show that the impact on

net flows as a fraction of GDP can go both ways. The increased volatility of gross flows always dominates, but this is a numerical result that does not have an intuitive explanation. We will show that when instead we divide capital flows by external assets we obtain a clean and intuitive result: financial globalization does not affect the volatility of gross flows, but reduces the volatility of net flows. It therefore unambiguously raises the correlation between inflows and outflows. Trade globalization also does not affect the volatility of gross flows, but raises the volatility of net flows. It therefore reduces the correlation between inflows and outflows. In the remainder of this section we will explicitly derive these results.

\subsection{Gross Flows}

Results for gross flows are the most straightforward. It is useful to repeat (50):

$$
\frac{G F}{\text { External Assets }}=\frac{2}{1+\beta+\xi}\left((1+\beta) \varepsilon^{\beta, A}+\varepsilon_{1}^{A}+\varepsilon^{I, A}\right)-4 \varepsilon^{z, A}
$$

When capital flows are scaled by external assets, gross flows do not depend on either the financial globalization parameter $m$ or the trade globalization parameter $1-\psi$.

Result 1 When gross flows are scaled by external assets, neither financial nor trade globalization 
affects the volatility of gross flows.

Especially for financial globalization, this result is consistent with the empirical analysis in Section 2 (Stylized Fact 2). Both cross section regressions and panel regressions find no effect of financial globalization on the volatility of gross capital flows when scaled by external assets and liabilities. The results for trade globalization are mixed as there is a positive effect of trade globalization on the gross capital flow volatility in cross section regressions and no effect in panel regressions.

The logic behind this result is as follows. Gross flows and gross external holdings both increase proportional to $m$. As a fraction of external holdings, gross flows are therefore independent of $m$. Consider for example an increase in $\varepsilon^{z, A}$. This is a portfolio shock that leads to a global retrenchment towards domestic assets. The retrenchment only applies to global investors in the model and is therefore proportional to $m$. The impact of the shock on gross flows is then proportional to $m$. Gross external assets and liabilities are also proportional to $m$ as only global investors hold foreign assets. Gross flows and positions are therefore both proportional to $m$. This is also consistent with the findings in Tables 3 and 4 that when gross flows are not scaled by external assets (scaled by GDP) financial globalization raises gross flow volatility (Stylized Fact 2). Trade globalization

only affects gross and net trade flows in the model, not gross capital flows. This does not depend on how we scale capital flows.

\subsection{Net Flows: Special Case}

Analyzing the impact of globalization on net capital flow volatility is a bit more involved. While it is possible to derive a closed form analytical solution of net flows as a function of the shocks, the expression is lengthy and its volatility is a highly non-linear function of both financial and trade globalization parameters. We therefore start with a special case, where Home and Foreign goods are perfect substitutes. This happens when $\omega=\infty$. In that case $p_{1}^{D}=p_{2}^{D}=0$. Imposing $N F=S-I$, using the expressions (47) and (48) for $N F$ and $S-I$, we can solve

$$
q^{D}=\frac{\frac{1-m}{1+\beta} \varepsilon_{1}^{D}+\frac{4 m}{\operatorname{var}(e r)} E\left(\varepsilon_{2}^{D}\right)+2 m \varepsilon^{z, D}+(1-m) \varepsilon^{\beta, D}-\frac{1}{\xi} \varepsilon^{I, D}}{\frac{A+m}{A+1}+\frac{1}{\xi}+\frac{4 m}{\operatorname{var}(e r)}}
$$

Define $\kappa=1+4 / \operatorname{var}(e r)$ and $\phi=1 /(1+\beta)$. Writing the denominator of $(52)$ as $D(m)$ and substituting (52) back into the net capital flow expression (47), we have

$$
\begin{aligned}
& \frac{N F}{\text { External Assets }}=\frac{\phi(1-m) \kappa}{D(m)} \varepsilon_{1}^{D}+\frac{\kappa+\phi(1-m)+(1 / \xi)}{D(m)} \varepsilon^{\beta, D} \\
& -2 \frac{(1-m) \phi+(1 / \xi)}{D(m)} \varepsilon^{z, D}-4 \frac{(1-m) \phi+(1 / \xi)}{D(m) \operatorname{var}(e r)} E\left(\varepsilon_{2}^{D}\right)-\frac{\kappa}{\xi D(m)} \varepsilon^{I, D}
\end{aligned}
$$

The absolute value of the coefficients in front of the shocks clearly declines as $m$ rises. The numerator of the ratios is either a negative function of $m$ or independent of $m$, while $D(m)$ in the denominator depends positively on $m$. It is therefore unambiguous that net capital flows, scaled 
by external assets, become less volatile as $m$ rises.

Result 2 In the special case where Home and Foreign goods are perfect substitutes, financial globalization reduces the volatility of net capital flows scaled by external assets.

This result is consistent with Stylized Fact 2. Both the panel and cross section regressions show that an increase in financial globalization reduces the volatility of net capital flows as a share of external assets in a statistically significant way.

Together with Result 1, the following corollary applies

Corollary 1 When Home and Foreign goods are perfect substitutes, financial globalization increases the correlation between capital inflows and outflows.

No results about trade integration apply in this special case. The parameter $\psi$ plays no role as Home and Foreign goods are perfect substitutes. Gross trade flows are then indeterminate.

To illustrate Result 2, Figure 3 shows the impact of a portfolio shift towards Foreign assets, which implies a negative value of $\varepsilon^{z, D}$. The same analysis applies when the shift towards Foreign assets is a result of drop in the expected relative Home dividend (decline in $E\left(\varepsilon_{2}^{D}\right)$ ). Figure 3 shows the $N F$ and $S-I$ schedules, both scaled by external assets. Abstracting from the other shocks, these schedules are

$$
\begin{aligned}
& \frac{N F}{\text { External Assets }}=\kappa q^{D}-2 \varepsilon^{z, D} \\
& \frac{S-I}{\text { External Assets }}=-\left(\frac{1-m}{(1+\beta) m}+\frac{1}{m \xi}\right) q^{D}
\end{aligned}
$$

The net outflow schedule is upward sloping as a function of $q^{D}$. An increase in the relative Home asset price lowers the expected excess return on Home assets, which leads to net capital outflows. The $S-I$ schedule is a downward sloping function of $q^{D} . S-I$ is equal to $0.5\left(S^{D}-I^{D}\right)$. A rise in $q^{D}$ raises relative Home consumption by native investors, which lowers relative Home saving. A rise in $q^{D}$ also raises relative Home investment through the Tobin's Q effect. Both reduce $S-I$. Only the $S-I$ schedule depends on $m$. The $S-I$ schedule is flatter the larger $m$. Figure 3 therefore shows the $S-I$ schedule for both a low $m$ (steep) and a high $m$ (flat).

A portfolio shift towards Foreign assets (drop in $\varepsilon^{z, D}$ ) shifts up the $N F$ schedule, while leaving the $S-I$ schedule unchanged. For a low $m$ the equilibrium is at point $\mathrm{B}$, while for a high $m$ it is at point C. Scaled by external assets, the response of net outflows to the portfolio shock is therefore smaller under more financial globalization.

The portfolio shift towards Foreign assets leads to an increase in the relative price of the Foreign assets, or a drop in $q^{D}$. The ultimate response of net capital flows depends on how responsive saving and investment are to the change in $q^{D}$. If they were not responsive at all, there will be no net capital flows. In that case $q^{D}$ drops enough, raising the relative return on the Home assets, to shift the portfolio allocation all the way back to its starting point. We have already seen that $S-I$ depends negatively on $q^{D}$, so that a drop in $q^{D}$ leads to net outflows. But the effect is dampened 
Figure 3: Equilibrium after portfolio shift towards foreign assets.

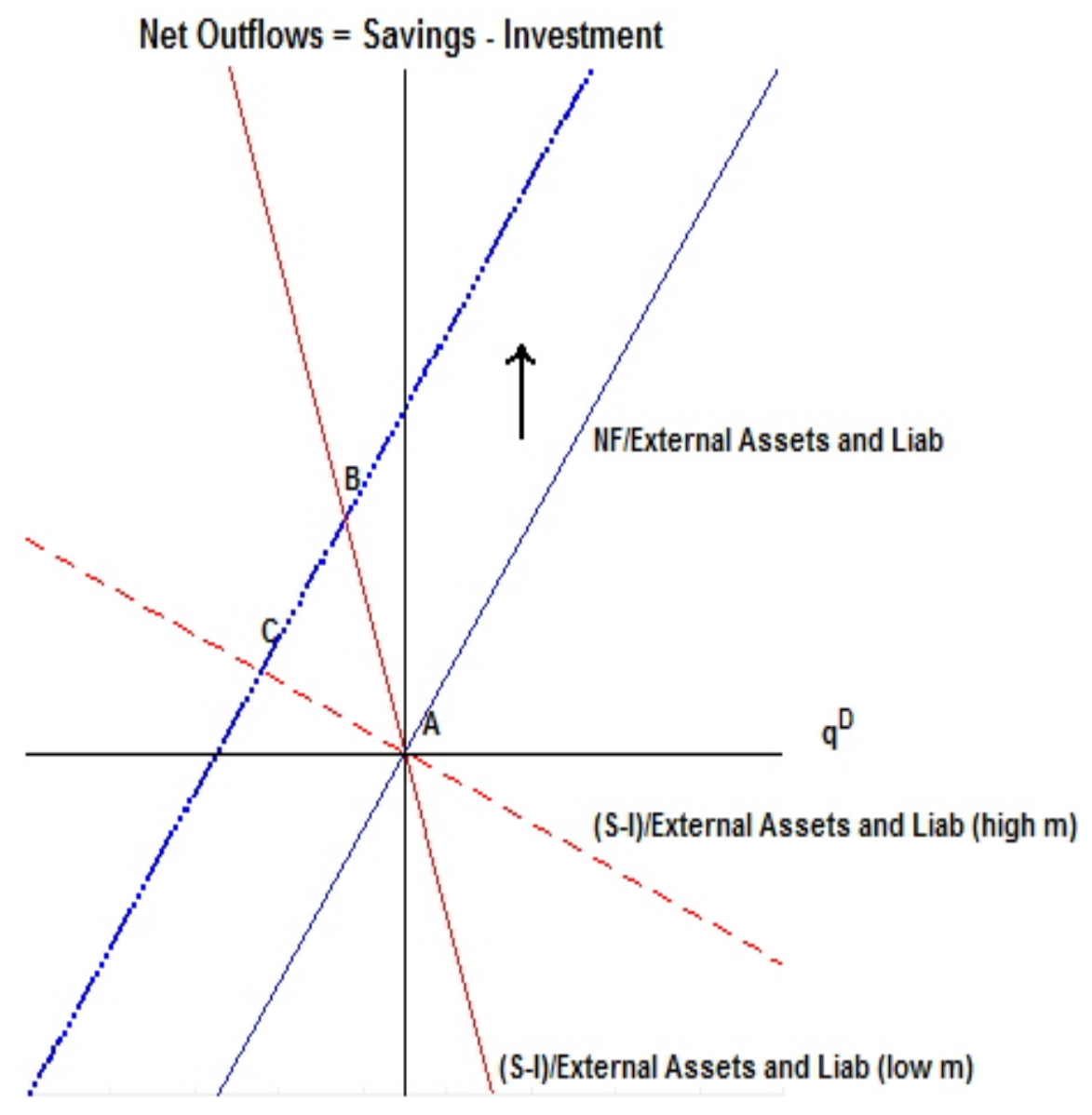

as $m$ is larger, for two reasons. First, a rise in $m$ implies that there are fewer native investors, which reduces the change in relative saving. Relative wealth and saving of global investors are unaffected. Second, both saving and investment are scaled by external assets. A rise in $m$ reduces the scaled saving and investment. For both of these reasons the net capital outflow response as a share of external assets is dampened as $m$ rises.

It is of interest to also consider what happens to net capital outflows if we do not scale by external assets. There are now two opposing forces. First, the $N F$ schedule will shift up more for a higher $m$. The portfolio shock is larger when there are more global investors that change their portfolio. This by itself implies that financial globalization increases net capital flows. On the other hand, more global investors also implies that there is more return arbitrage. More investors change portfolios in response to a change in the expected return difference. A smaller change in $q^{D}$ is needed to clear markets. This effect, which corresponds to a steeper $N F$ schedule, leads financial globalization to dampen net capital flows. ${ }^{7}$ Numerically we find that net capital outflows first increase and then drop in size as we keep raising $m$ from 0 to 1 . This is consistent with the mixed results in Tables 3 and 4, where the effect of financial globalization on the volatility of net flows relative to GDP is insignificant or positive and small (Stylized Fact 2).

\footnotetext{
${ }^{7}$ It also remains the case that a higher $m$ implies a smaller relative saving response as only relative saving of native investors changes with $q^{D}$. This dampens the effect of financial globalization on net capital flows.
} 
The standard deviation of gross flows increases proportionately with $m$ when capital flows are not scaled by external assets. Even if the volatility of net capital flows increases with $m$, the ratio of the volatilities of gross and net flows will still be dominated by the increased volatility if gross flows. But this is not an obvious result. Scaling by external assets makes it much more transparent that the volatility of gross flows rises relative to the volatility of net flows as $m$ increases, generating a higher correlation between inflows and outflows.

\subsection{Net Capital Flows: The General Case}

We finally consider the general case where $\omega$ is finite, so that Home and Foreign goods are imperfect substitutes. In that case we need to solve for relative goods prices as well and it is hard to get clean analytical results. We therefore illustrate the impact of the various shocks on net capital flows through a numerical illustration. The drawback of this is that we need to pick specific parameters. But we find that the parameter values have little qualitative effect on the results.

Figures 4 through 7 report the results. We set $\beta=0.95, \omega=2, \xi=2.5$ and $\operatorname{var}(\operatorname{er})=0.04 .^{8}$ When varying the degree of financial globalization with the parameter $m$, we hold $\psi=0.86$. When varying the degree of trade integration, we hold $m=0.2$.

Figure 4 reports the impact of shocks on net capital flows scaled by external assets when varying $m$ from 0 to 1 . The shocks are normalized to 1 or -1 , with the sign such that the response of net capital flows is positive. Figure 4 shows that for all shocks an increase in $m$ reduces the size of net capital flows scaled by external assets. ${ }^{9}$ The numerical analysis implies the following finding.

Result 3 When Home and Foreign goods are imperfect substitutes, numerical analysis implies that an increase in financial globalization reduces the impact of shocks on net capital flows scaled by external assets. Financial globalization therefore reduces the volatility of net capital flows as a fraction of external assets.

Thus the results for the special case where goods are perfect substitutes in section 4.2 generalizes to the case where goods are imperfect substitutes.

Figure 5 shows that a very different picture emerges when net outflows are scaled by GDP. In some cases the size of net outflows increases monotonically with the financial globalization parameter $m$. In others it first increases and then decreases with $m$. These results are not inconsistent with the ambiguous effect of financial globalization on the volatility of net capital flows as a share of GDP found in the data when globalization increases (Stylized Fact 2).

Figure 6 shows the impact of trade globalization. Define Trade as exports or imports in the absence of shocks. As we vary $\psi$ from 1 to 0.5 , Trade/GDP (on the horizontal axis) changes

\footnotetext{
${ }^{8}$ The variance of the excess return is endogenous, but we can always set the standard deviations of the shocks to match any variance of the excess return.

${ }^{9}$ The only small footnote to this is that for a relative income shock the net outflow response turns slightly negative for large enough $\mathrm{m}$. This is because a positive Home productivity shock leads to negative net investment income, which makes the current account slightly negative.
} 
from 0 to 0.5 . In all cases net outflows increase as we increase trade globalization. ${ }^{10}$ The following result applies.

Result 4 When Home and Foreign goods are imperfect substitutes, numerical analysis implies that an increase in trade globalization increases the impact of shocks on net capital flows, therefore increasing the volatility of net capital flows.

In the case of trade globalization, it does not matter for the theory whether we scale by external assets or GDP as neither depend on $\psi$.

Since we have already established that neither financial nor trade globalization affect the volatility of gross capital flows as a share of external assets, the following corollary applies (subject to minor qualifications noted above).

Corollary 2 When Home and Foreign goods are imperfect substitutes, financial globalization increases the correlation between capital inflows and outflows, while trade globalization decreases the correlation between capital inflows and outflows.

As a final exercise we consider the theoretical impact of jointly increasing financial and trade globalization. For this purpose we vary $m$ from 0 to 1 , while setting $1-\psi=0.5 m$. This leads to a gradual change from financial and trade autarky to perfect integration along both dimensions. The financial and trade globalization measures stay in a constant ratio. Figure 7 reports the results, with net capital flows scaled by external assets. For all shocks net capital flows decline with the joint globalization. Since neither financial not trade globalization affects the volatility of gross capital flows, the following result applies.

Result 5 When Home and Foreign goods are imperfect substitutes, numerical analysis implies that a proportional joint increase in trade and financial globalization increases the correlation between capital inflows and outflows.

While we have seen that financial and trade globalization have an opposite effect on the correlation between inflows and outflows, this result says that financial globalization has a larger effect when they are changed proportionately. This is consistent with Stylized Fact 4 from the empirical analysis. Of course in the data the globalization has been highly skewed towards financial globalization. As our results have shown, this further reinforces the increase in the correlation between capital inflows and outflows.

\footnotetext{
${ }^{10}$ There is again a small footnote with regards to relative income shocks, where the impact on net outflows starts slightly negative at trade levels near zero before it turns positive. This is again associated with negative net investment income.
} 
Figure 4: Impact of financial globalization on net capital flows (as a share of external assets and liabilities).
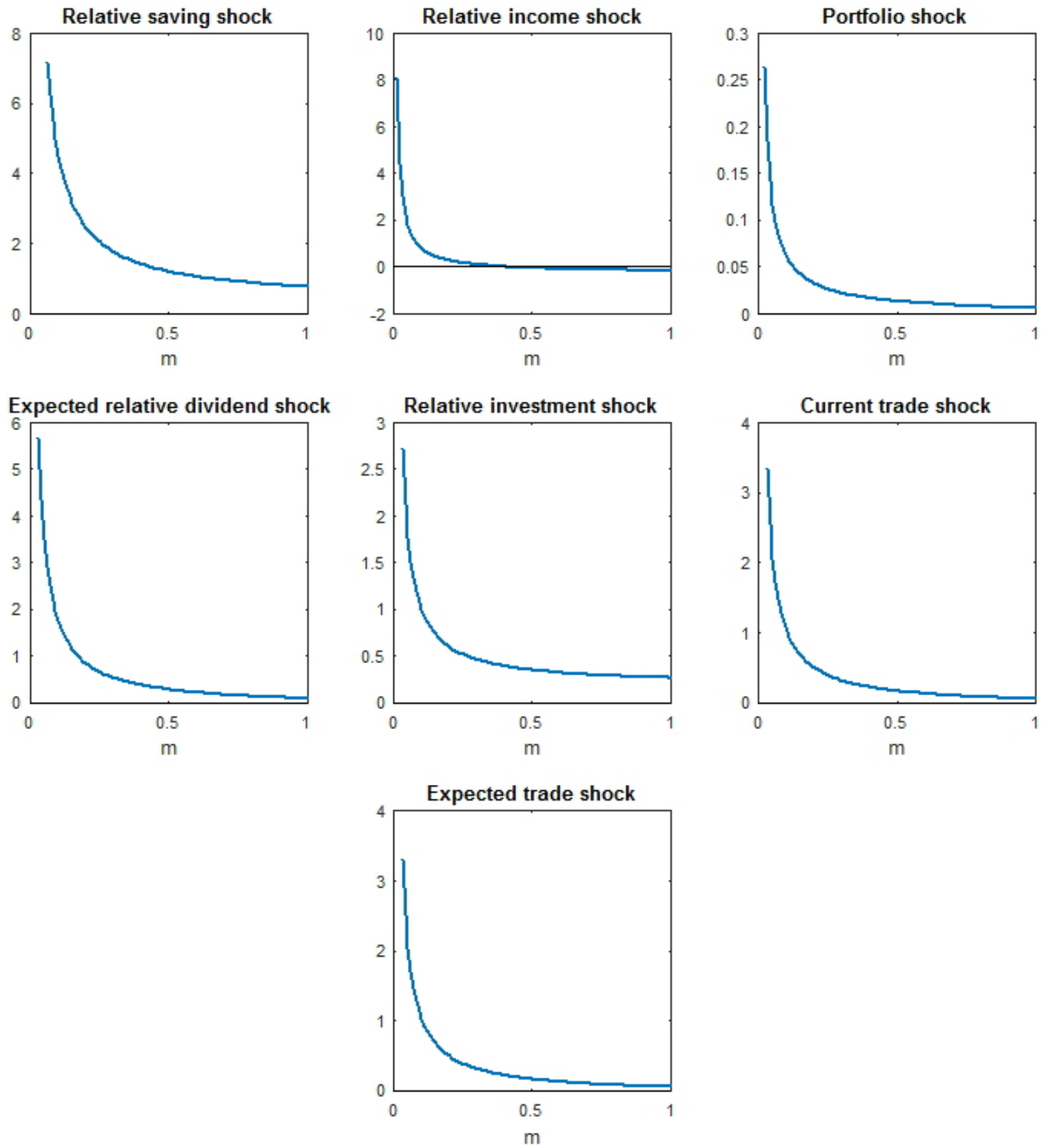

Notes: The relative saving shock is $\varepsilon^{\beta, D}=1$. The relative income shock is $\varepsilon_{1}^{D}=1$. The portfolio shock is $\varepsilon^{z, D}=-1$. The expected relative dividend shock is $E\left(\varepsilon_{2}^{D}\right)=-1$. The relative investment shock is $\varepsilon^{I, D}=-1$. The trade shock is $\varepsilon_{1}^{\psi, D}=-1$. The expected trade shock is $E\left(\varepsilon_{2}^{\psi, D}\right)=1$. 
Figure 5: Impact of financial globalization on net capital flows (as a share of GDP).
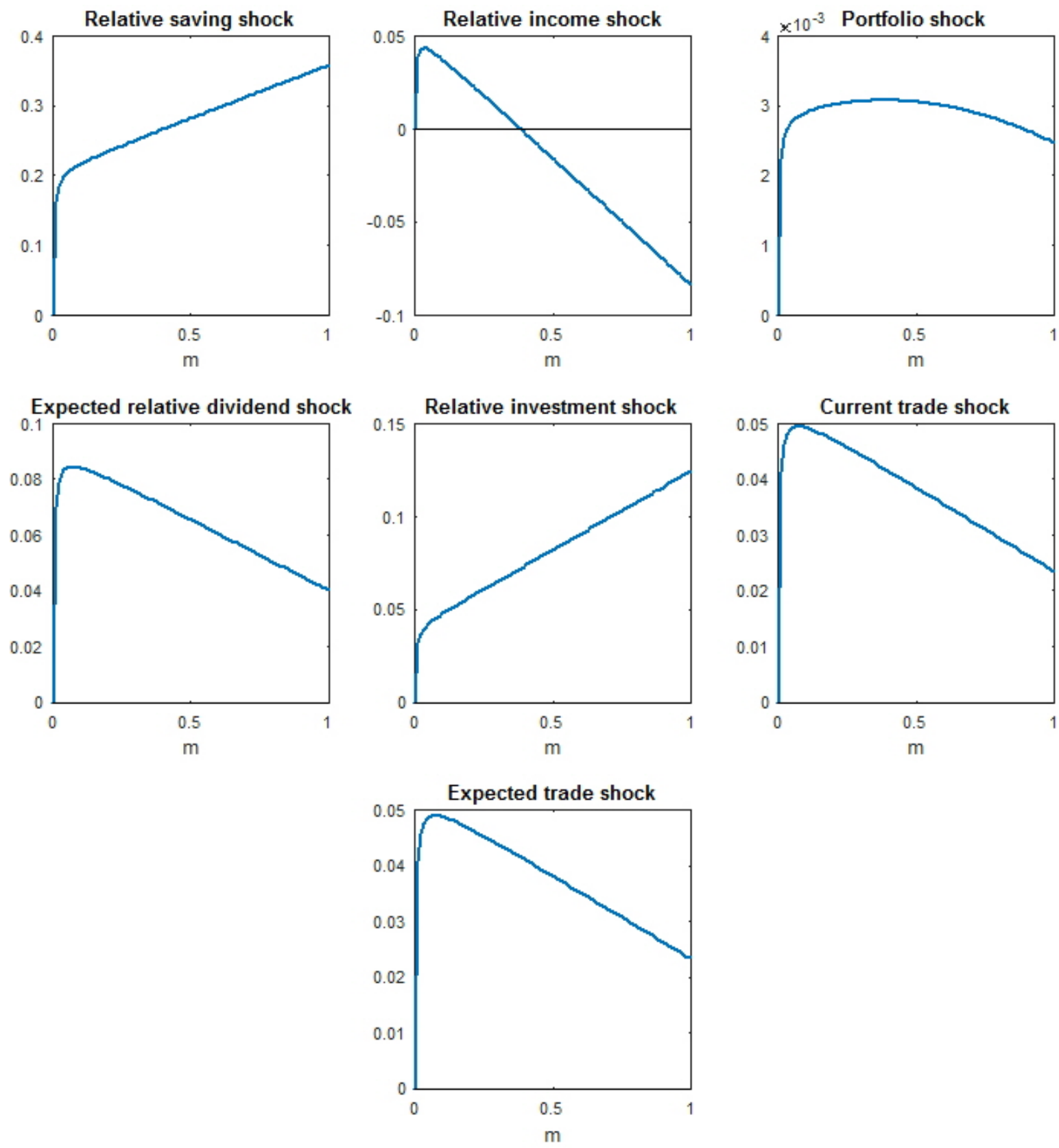

Notes: The relative saving shock is $\varepsilon^{\beta, D}=1$. The relative income shock is $\varepsilon_{1}^{D}=1$. The portfolio shock is $\varepsilon^{z, D}=-1$. The expected relative dividend shock is $E\left(\varepsilon_{2}^{D}\right)=-1$. The relative investment shock is $\varepsilon^{I, D}=-1$. The trade shock is $\varepsilon_{1}^{\psi, D}=-1$. The expected trade shock is $E\left(\varepsilon_{2}^{\psi, D}\right)=1$. 
Figure 6: Impact of trade globalization on net capital flows (as a share of external assets and liabilities).
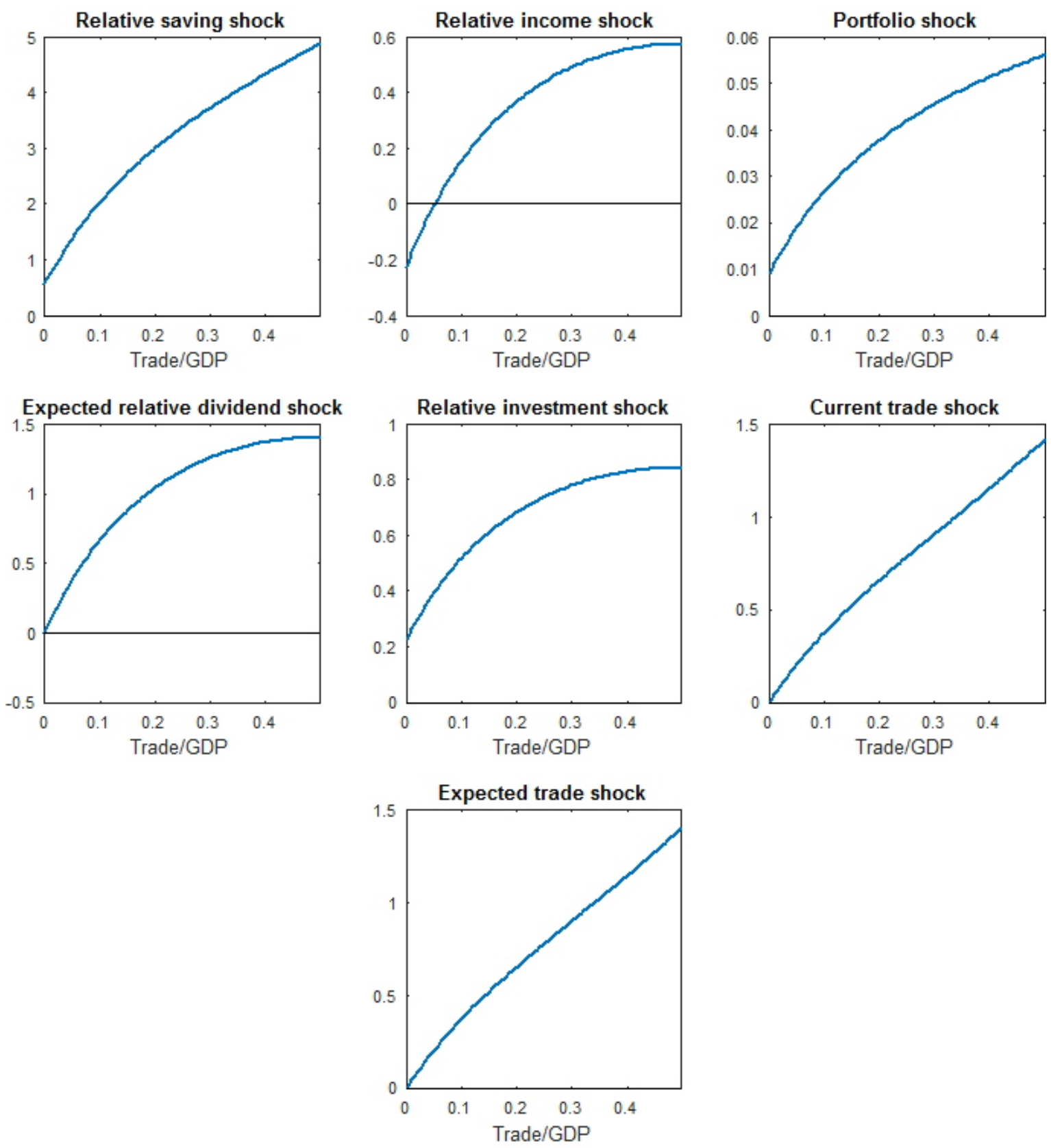

Notes: The relative saving shock is $\varepsilon^{\beta, D}=1$. The relative income shock is $\varepsilon_{1}^{D}=1$. The portfolio shock is $\varepsilon^{z, D}=-1$. The expected relative dividend shock is $E\left(\varepsilon_{2}^{D}\right)=-1$. The relative investment shock is $\varepsilon^{I, D}=-1$. The trade shock is $\varepsilon_{1}^{\psi, D}=-1$. The expected trade shock is $E\left(\varepsilon_{2}^{\psi, D}\right)=1$. 
Figure 7: Impact of joint trade and financial globalization on net capital flows (as a share of external assets and liabilities).
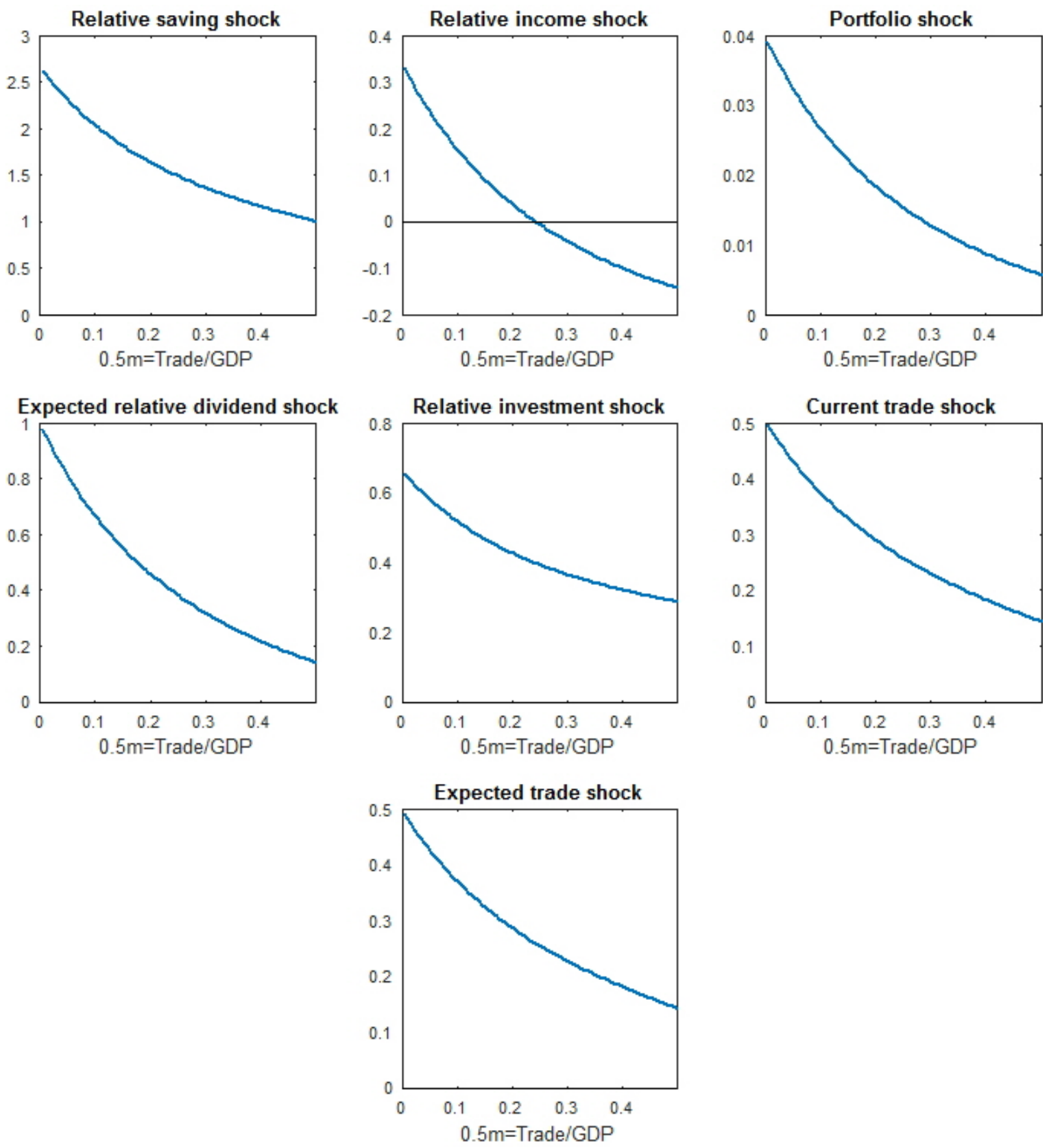

Notes: The relative saving shock is $\varepsilon^{\beta, D}=1$. The relative income shock is $\varepsilon_{1}^{D}=1$. The portfolio shock is $\varepsilon^{z, D}=-1$. The expected relative dividend shock is $E\left(\varepsilon_{2}^{D}\right)=-1$. The relative investment shock is $\varepsilon^{I, D}=-1$. The trade shock is $\varepsilon_{1}^{\psi, D}=-1$. The expected trade shock is $E\left(\varepsilon_{2}^{\psi, D}\right)=1$. 


\section{Conclusion}

We have aimed to explain the rapidly increasing correlation between capital inflows and outflows seen in the data and the much higher correlation in more advanced countries. Both empirical evidence and theory point to a clear culprit, the increased level of financial globalization measured by the increased stock of external assets and liabilities. Trade globalization has the exact opposite effect, but has been significantly dominated by financial globalization in the last several decades. Even if trade and financial globalization had grown proportionally, we find that the higher correlation between inflows and outflows due to financial globalization would still have dominated.

A natural direction for future work is to extend the theoretical framework developed here to a multi-country setup with countries varying in terms of their extent of financial and trade integration, their size, and the magnitude of country-specific shocks. This will allow us to consider additional stylized facts, such as the co-movement of capital flows across countries (global financial cycle) and the correlation between bilateral inflows and outflows. 


\section{References}

[1] Bacchetta, Philippe and Eric van Wincoop (2017), "Gradual Portfolio Adjustment: Implications for Global Equity Portfolios and Returns," NBER working paper 23363.

[2] Bianchi, Javier, Juan Carlos Hatchondo and Leonardo Martinez (2016), "International Reserves and Rollover Risk," Federal Reserve Bank of Minneapolis Working Paper 735.

[3] Brennan, Michael J. and H. Henry Cao (1997), "International Portfolio Investment Flows," The Journal of Finance 52, 1851-1880

[4] Broner, Fernando, Tatiana Didier, Aitor Erce and Sergio L. Schmukler (2013), "Gross Capital Flows: Dynamics and Crises," Journal of Monetary Economics 60, 113-133.

[5] Cerutti, Eugenio, Stijn Claessens and Andrew K. Rose (2017), "How Important is the Global Financial Cycle? Evidence from Capital Flows," working paper, Berkeley.

[6] Davis, J. Scott (2015), "The Cyclicality of (Bilateral) Capital Inflows and Outflows," Working Paper 247, Federal Reserve Bank of Dallas, Globalization and Monetary Policy Institute.

[7] Devereux, Michael B., and Charles Engel (2002), "Exchange Rate Pass-through, Exchange Rate Volatility, and Exchange Rate Disconnect," Journal of Monetary Economics 49, 913-940.

[8] Forbes, Kristin J. and Francis E. Warnock (2012), "Capital Flow Waves: Surges, Stops, Flight, and Retrenchment," Journal of International Economics 88, 235-251.

[9] Gabaix, Xavier and Matteo Maggiori (2015), "International Liquidity and Exchange Rate Dynamics," Quarterly Journal of Economics 130(3), 1369-1420.

[10] Giannetti, Mariassunta and Luc Laeven (2012), "The Flight Home Effect: Evidence from the Syndicated Loan Market during Financial Crises," Journal of Financial Economics 104 (1), 23-43

[11] Gourio, Francois, Michael Siemer and Adrien Verdelhan (2016), "Uncertainty and International Capital Flows," working paper, MIT Sloan.

[12] Hau, Harald (1998), "Competitive Entry and Endogenous Risk in the Foreign Exchange Market," Review of Financial Studies 11(4), 757-787.

[13] Itskhoki, Oleg and Dmitry Mukhin (2017), "Exchange Rate Disconnect in General Equilibrium," working paper, Princeton University.

[14] Kalemli-Ozcan, Sebnem, Elias Papaioannou and Fabrizio Perri (2013), "Financial Regulation, Financial Globalization, and the Synchronization of Economic Activity," Journal of Finance 68(3), 1179-1228

[15] Milesi-Ferretti, Gian-Maria and Cedric Tille (2011), "The Great Retrenchment: International Capital Flows during the Global Financial Crisis," Economic Policy 26(66), 285-342. 
[16] Okawa, Yohei and Eric van Wincoop (2012), "Gravity in International Finance," Journal of International Economics 87(2), 205-215.

[17] Portes, Richard and Helene Rey (2005), "The Determinants of Cross-Border Equity Flows," Journal of International Economics 65, 269-296.

[18] Rey, Helene (2013), "Dilemma not Trilemma: The Global Financial Cycle and Monetary Policy," Jackson Hole Conference Proceedings, Kansas City Fed.

[19] Tille, Cedric and Eric van Wincoop (2010), "International Capital Flows," Journal of International Economics 80(2), 157-175.

[20] Tille, Cedric and Eric van Wincoop (2014), "International Capital Flows under Dispersed Private Information," Journal of International Economics 93(1), 31-49.

[21] Wang, Jiang (1994), "A Model of Competitive Stock Trading Volume," Journal of Political Economy 102, 127-168 